\title{
Population ecology of the sea lamprey (Petromyzon marinus) as an invasive species in the Laurentian Great Lakes and an imperiled species in Europe
}

\author{
Michael J. Hansen · Charles P. Madenjian · Jeffrey W. Slade • \\ Todd B. Steeves • Pedro R. Almeida • Bernardo R. Quintella
}

Received: 3 December 2015/ Accepted: 16 June 2016/Published online: 22 June 2016

(C) The Author(s) 2016. This article is published with open access at Springerlink.com

\begin{abstract}
The sea lamprey Petromyzon marinus (Linnaeus) is both an invasive non-native species in the Laurentian Great Lakes of North America and an imperiled species in much of its native range in North America and Europe. To compare and contrast how understanding of population ecology is useful for control programs in the Great Lakes and restoration programs in Europe, we review current understanding of the population ecology of the sea lamprey in its native and introduced range. Some attributes of sea
\end{abstract}

Jeffrey W. Slade was retired from U.S. Fish and Wildlife Service, Ludington Biological Station, 229 S. Jebavy Drive, Ludington, Michigan 49431, USA.

\section{J. Hansen ( $₫)$}

Hammond Bay Biological Station, Great Lakes Science

Center, U.S. Geological Survey, 11188 Ray Road,

Millersburg, MI 49759, USA

e-mail: michaelhansen@usgs.gov

C. P. Madenjian

Great Lakes Science Center, U.S. Geological Survey, 1451 Green Road, Ann Arbor, MI 48105, USA

e-mail: cmadenjian@usgs.gov

J. W. Slade

Ludington, MI, USA

e-mail: 17slade17@gmail.com

\section{T. B. Steeves}

Sea Lamprey Control Centre, Fisheries and Oceans

Canada, 1219 Queen St. East, Sault Ste. Marie,

ON P6A 2E5, Canada

e-mail: Mike.Steeves@dfo-mpo.gc.ca lamprey population ecology are particularly useful for both control programs in the Great Lakes and restoration programs in the native range. First, traps within fish ladders are beneficial for removing sea lampreys in Great Lakes streams and passing sea lampreys in the native range. Second, attractants and repellants are suitable for luring sea lampreys into traps for control in the Great Lakes and guiding sea lamprey passage for conservation in the native range. Third, assessment methods used for targeting sea lamprey control in the Great Lakes are useful for targeting habitat protection in the native range. Last, assessment methods used to quantify numbers of all life stages of sea lampreys

\footnotetext{
P. R. Almeida

Departamento de Biologia, Escola de Ciências e Tecnologia, MARE - Centro de Ciências do Mar e do Ambiente, Universidade de Évora, Largo dos Colegiais, 7004-516 Évora, Portugal e-mail: pmra@uevora.pt

B. R. Quintella

Departamento de Biologia Animal, Faculdade de Ciências, MARE - Centro de Ciências do Mar e do Ambiente, Universidade de Lisboa, Campo Grande, 1749-016 Lisbon, Portugal e-mail: bsquintella@fc.ul.pt
} 
would be appropriate for measuring success of control in the Great Lakes and success of conservation in the native range.

Keywords Sea lamprey · Population ecology . Management · Conservation

\section{Introduction}

The sea lamprey Petromyzon marinus (Linnaeus) is both an invasive exotic species in the Laurentian Great Lakes of North America and an imperiled species in much of its native range along the north Atlantic coasts of North America and Europe (Fig. 1). In the Laurentian Great Lakes, the sea lamprey evidently invaded the Great Lakes from the Atlantic Ocean (Christie and Goddard 2003; Eshenroder 2014), and were first found in Lake Ontario in 1835 (although this date has been disputed by Eshenroder 2014), Lake Erie in 1921, Lake Michigan in 1936, Lake Huron in 1937, and Lake Superior in 1938 (Applegate 1950; Lawrie 1970; Smith 1979; Smith and Tibbles 1980; Smith 1985). By the 1950s, sea lampreys were abundant in all Great Lakes, where they imposed high mortality on nearly all teleost species, but especially the lake trout Salvelinus namaycush (Hansen 1999). Control of sea lamprey populations began in the 1950s, initially with mechanical and electrical barriers to upstream migration, and later with a selective pesticide, 3-trifluoromethyl-4-nitrophenol (TFM; Smith and Tibbles 1980). Suppression of sea lamprey populations continues to rely on TFM, but was expanded to also include use of an integrated program of physical (barriers and traps) and biological (sterile-male releases) control methods (Christie and Goddard 2003), although sterile-male releases were suspended until further research could be completed to confirm its efficacy.

In its native range, the sea lamprey is considered threatened in France, Spain, and Portugal, European countries where the main populations are found, although the species is considered of Least Concern according to the International Union for Conservation of Nature (IUCN) Red List of Threatened Species, and the European Red List of Freshwater Fishes (Mateus et al. 2012). The sea lamprey is highly valued as a food fish where populations are large enough to be exploited (Quintella 2006), so commercial overfishing is a serious threat for the species in areas such as the Iberian Peninsula (Mateus et al. 2012) and elsewhere in Europe (Maitland et al. 2015). In general, however, the sea lamprey has declined over the last 25 years in Europe from a combination of (1) habitat loss associated with dam construction, (2) degradation of water quality from mining, industrial, and urban development, (3) direct loss of habitat by sand extraction and dredging, (4) overfishing, and (5) changes in water quality (temperature) and quantity
Fig. 1 Worldwide distribution of native (black shading North Atlantic Ocean) and non-native (gray shading Laurentian Great Lakes, North America) sea lamprey populations

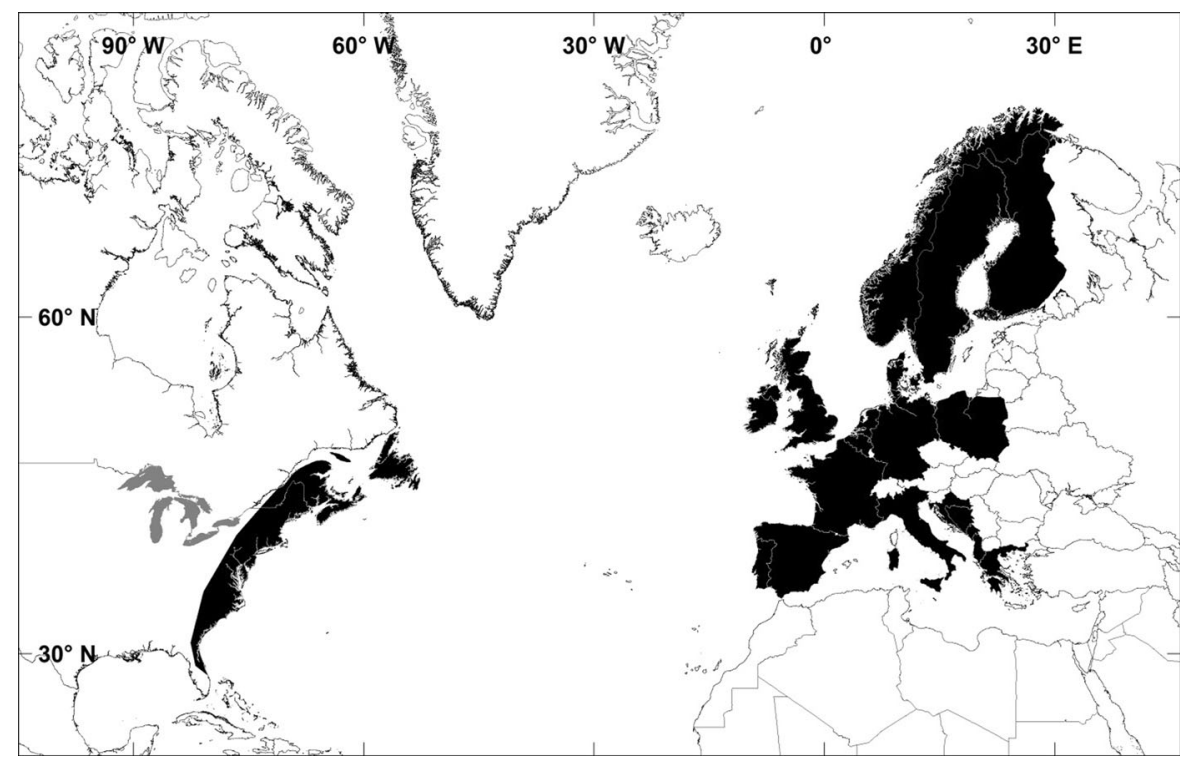


associated with climate change (Mateus et al. 2012). To enable population recovery, lost or damaged habitat must be restored, while sustainably managing commercial fisheries (Mateus et al. 2012).

The purpose of this review is to synthesize and relate the state of knowledge concerning the population ecology of sea lamprey between Continents, to increase understanding of how knowledge of population ecology bears on control programs in the Great Lakes and restoration programs in Europe. First, current understanding of the life cycle is reviewed, including adult life stage, reproduction, larval life stage, metamorphosis, juvenile life stage, feeding, and effects on host species, pointing out when present differences between North American versus European populations and/or landlocked versus anadromous form. Second, implications for future status of the species are reviewed, including how global climate change will affect sea lamprey population ecology in the Great Lakes and Europe, which attributes of sea lamprey population ecology can be used to control populations in the Great Lakes, which attributes of sea lamprey population ecology can be used to restore and conserve populations in Europe, which attributes of sea lamprey population ecology are in need of further study for management of the species worldwide, and how understanding of population ecology bears on both control programs in the Great Lakes and restoration programs in Europe. For each topic below, we attempted to include information for both non-native populations in the Laurentian Great Lakes and native populations in Europe, although gaps in available information prevented complete coverage of all topics in both the Great Lakes and Europe.

\section{Overview}

Lampreys have an unusual life cycle for a vertebrate because of a relatively long larval life stage and a relatively short adult life stage. A complete life cycle of a sea lamprey takes at least 4-5 years (range $=3-10+$ years), including $12-18$ months (minimum of 14 months for anadromous populations) in the juvenile and adult life stage (Fig. 2). The long larval life stage, a disadvantage for most anadromous fishes because of increased risk of predation during this vulnerable period, is more beneficial than detrimental to the sea lamprey because larvae spend that period of life burrowed in river sediments and are mostly sedentary. Osmotic, bioenergetics, and predationexposure costs in moving between riverine and oceanic or lake ecosystems are compensated by a reduced predation on early life stages in riverine environments and access to greater trophic resources in marine or lake environments (Gross 1987). For the sea lamprey, in particular, richness of the marine or lake diet is measured not only in terms of numbers of potential host species and individuals, but also the size of parasitized species needed to sustain an adult sea lamprey.

Debate regarding the native or non-native origin of sea lampreys in Lake Ontario continues (Siefkes et al. 2013; Eshenroder 2014), but once established in the upper Great Lakes, sea lampreys spread rapidly to reproduce in $\sim 500$ Great Lakes tributaries (Lake Superior $=161, \quad$ Lake $\quad$ Michigan $=126, \quad$ Lake Huron $=122$, Lake Erie $=23$ and Lake Ontario $=66$ ). Following their invasion, sea lampreys spread rapidly throughout the five Laurentian Great Lakes and are now found in streams of Minnesota (Eddy and Underhill 1974), Wisconsin (Becker 1983), Michigan (Applegate 1950), Illinois (Smith 1979), Indiana (Gerking 1955), Ohio (Trautman 1981), Pennsylvania (Emery 1985), New York (Smith 1985), and throughout Ontario (Adair and Sullivan 2013). As evidenced by marking on host fishes, juveniles are distributed throughout open waters of all Great Lakes, and larvae are currently distributed in streams from eastern Lake Ontario to western Lake Superior.

\section{Adult life stage}

Following completion of their 1-2 year-long marine trophic phase (Beamish 1980; Silva et al. 2013a, b), anadromous adult sea lampreys migrate upstream to river stretches where they build nests, spawn, and die (Larsen 1980; Moser et al. 2015). Passage from sea to fresh water is a stressful stage of migration, so adults use estuaries to acclimate from salt-water to freshwater osmoregulation (Bartels and Potter 2007). The spawning migration ranges from September to March along the east coast of North America (Beamish 1980); begins in December, peaks in February-March, and ends with spawning in April-June in Southwestern Europe Portuguese rivers (Almeida et al. 2000; 
Fig. 2 Duration of and general habitat characteristics used by spawning adult, larval, outmigrating, and parasitic juvenile sea lamprey life stages in the Great Lakes (Great Lakes Fishery Commission)

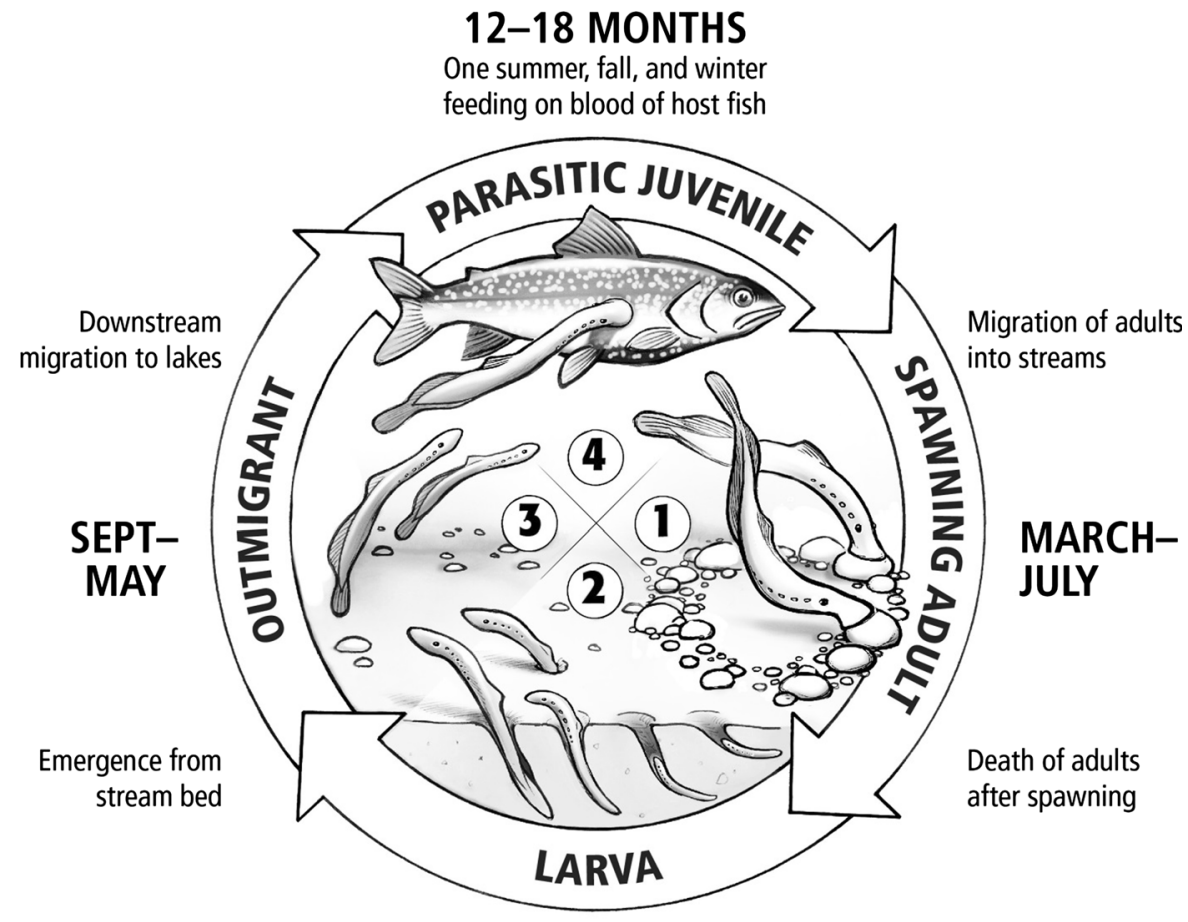

3-10+ YEARS
Oliveira et al. 2004); and begins in February, continues through May-June, and ends with spawning between the end of May and early July in the Northwestern Europe Severn River, Britain (Hardisty 1986). Upstream spawning migration is triggered by flow variation and temperature, so increased migratory activity in periods of high discharge is likely a behavior adopted by sea lampreys to overcome difficult passage stretches to reach upstream spawning areas (Almeida et al. 2002a; Andrade et al. 2007; Binder et al. 2010). Regulated increased river discharge at night (i.e. hydropeaking) seems to stimulate lamprey movement, although reduced ground speed of upstream movement has also been observed (Almeida et al. 2002a).

Adult sea lampreys do not appear to home to natal streams (Bergstedt and Seelye 1995; Waldman et al. 2008; Swink and Johnson 2014), but rather, select spawning streams through innate attraction using other sensory cues (Sorensen and Vrieze 2003; Li et al. 2003; Vrieze et al. 2010, 2011). In the Great Lakes, adults from the same stream and cohort migrate into numerous streams throughout one or more of the Great
Lakes, and tagged juveniles have been recaptured as adults in streams more than $400 \mathrm{~km}$ from their natal stream (Swink and Johnson 2014; Johnson et al. 2014; U.S. Fish and Wildlife Service, unpublished data). Mechanistic factors driving these movements are still unknown, although adults locate spawning streams using a three-phase odor-mediated strategy that includes searching a shoreline while casting vertically, followed by stream-water-induced turning toward a stream mouth, where they ascend using rheotaxis (Vrieze et al. 2011; Meckley et al. 2014). In the Great Lakes, adult sea lampreys are highly selective in the choice of spawning streams (Morman et al. 1980), and choose streams with high larval density (Moore and Schleen 1980), signaled by bile acid-based pheromones released by larvae (Bjerselius et al. 2000). Lack of homing is also evident from genetic studies of spawning migrants returning from the Atlantic Ocean (Bryan et al. 2005; Waldman et al. 2008). However, fatty acids and morphology of sea lampreys from major Portuguese rivers indicate that dispersion in the ocean may be limited, which suggests some degree of geographical fidelity when adults return from feeding 
areas (Lança et al. 2014). Further, absence of genetic exchange among sea lamprey populations spawning in the western and eastern Atlantic suggests adults do not intermingle (Rodríguez-Muñoz et al. 2004).

Adult sea lampreys congregate at stream mouths from January through March each year, but the precise timing of upstream migration differs with latitude (Moser et al. 2015). In the Great Lakes, upstream migration of adults begins in March-April (Applegate 1950) when water temperature reaches $\sim 15^{\circ} \mathrm{C}$ (Binder et al. 2010). In Europe, adult begin to migrate into streams in December-January, with the peak of migration in February-April, and spawning in AprilMay. Migratory activity is stimulated when water temperature increases daily, and is suppressed when water temperature decreases daily (Binder et al. 2010). Migration distance depends on river size, location of suitable spawning areas, and length of river stretches downstream of impassable barriers (Hardisty 1986). In Great Lakes streams without natural or man-made barriers, adult sea lampreys migrate more than $100 \mathrm{~km}$ upstream. In the Iberian Peninsula, $80 \%$ of accessible sea lamprey habitat was lost by obstruction of lower stretches of all major rivers: historical available habitat in the main stretch of the larger rivers was $516 \mathrm{~km}$ in the Douro, $633 \mathrm{~km}$ in the Tagus, $648 \mathrm{~km}$ in the Guadiana, $394 \mathrm{~km}$ in the Guadalquivir, and $680 \mathrm{~km}$ in the Ebro (Mateus et al. 2012). In Portugal, the present distribution of the sea lamprey is quite limited, with spawning areas located below impassable dams, with the upstream limit ranging between 27 km (Cávado River) and 150 km (Tagus River) (Almeida et al. 2002b; Mateus et al. 2012). In Britain, spawning habitat lies within $10-100 \mathrm{~km}$ of the tidal limit (Hardisty 1986). Sea lampreys historically migrated upstream $850 \mathrm{~km}$ in the Rhine River, Europe (Hardisty 1986) and $320 \mathrm{~km}$ in the Delaware and Susquehanna rivers, North America (Bigelow and Schroeder 1948), until construction of the Conowingo Dam near the mouth of the Susquehanna in 1928 obstructed migration (Waldman et al. 2009).

Adult sea lampreys migrating upstream have ceased feeding, the digestive system has atrophied and is nonfunctional, and the sea lamprey invests remaining energy in gamete production, nest construction and spawning. Lampreys are negatively phototaxic, so move upstream in fresh water primarily during dusk and darkness (Almeida et al. 2000, 2002a) and seek refuge before dawn (Andrade et al. 2007). The adaptive value of nocturnal behavior might be related to the greater protection afforded by darkness. When swimming through slow river stretches, adult sea lampreys can maintain constant activity at an average ground speed of 0.76 body lengths/s (Quintella et al. 2009), although typical swimming is at a ground speed of 0.2-0.4 body lengths/s (Andrade et al. 2007). Adults seek cool, well-oxygenated water with a unidirectional flow over rock, gravel, and sand substrate (Applegate 1950; Hardisty and Potter 1971b). Nests are typically constructed by males using their mouth to move stones, while flushing smaller particles from the nest with rapid body movements. Spawning pairs intertwine in the nest, and with a series of convulsions, release milt and eggs into the nest. Sea lampreys are semelparous, so they die shortly after spawning (Applegate 1950; Johnson et al. 2015a, b).

Mortality of adult sea lampreys prior to spawning is poorly understood, but has been observed (Applegate 1950), although dead carcasses observed in one stream may have been caused by spawning or chemosterilization (Hanson and Manion 1980). Natural mortality of adult sea lampreys introduced into two Lake Ontario tributaries ranged from 6 to $30 \%$ and mortality from predation ranged from 1 to $11 \%$ (O'Connor 2001). Mortality from predation, particularly on nest sites has been assumed to be relatively small, although predators could prevent successful spawning in streams with few adults (Applegate 1950; Morman et al. 1980). The Eurasian otter (Lutra lutra Linnaeus) commonly prey sea lamprey adults during spawning period with estimated predation rates around $8 \%$ (Andrade et al. 2007; Maitland et al. 2015). Emigration of adult sea lampreys introduced into streams ranged from 8 to $49 \%$ within a spawning season (Manion and McLain 1971; Hanson and Manion 1980; Kelso and Gardener 2000; Dolinsek et al. 2014). Depending upon their state of maturation, sea lampreys that emigrated from streams may die (Applegate 1950; Applegate and Smith 1951) or move to another stream to spawn (Dolinsek et al. 2014).

Lamprey can use their oral disc to attach to substrate and rest between bouts of swimming, a strategy referred to as "burst-and-attach" (Quintella et al. 2009). In areas of fast water velocity, a combination of intermittent burst swimming and periods of rest when attached to the substrate is characteristic behavior (Applegate 1950; Hardisty and Potter 1971b; Haro and Kynard 1997; Mesa et al. 
2003; Quintella et al. 2004). This highly active swimming is the most energy-inefficient form of activity (Beamish 1978) and can only be achieved for short periods. Nevertheless, absence of a swim bladder to sustain neutral buoyancy (Hardisty and Potter 1971b) and less-efficient anguilliform propulsion used by lampreys (Webb 1978; van Ginneken et al. 2005) makes this pattern the most energetically conservative for overcoming rapid flow or man-made obstacles (Quintella et al. 2004).

Adult anadromous sea lampreys are larger in Europe than in North America, and exhibit latitudinal and temporal trends, with body size increasing from north to south, and length of spawners increasing from 1980 to 2005 (Beaulaton et al. 2008). In Europe, adults are the largest in Portugal (Beaulaton et al. 2008), where they averaged $85 \mathrm{~cm}$ in TL and $1.2 \mathrm{~kg}$ in weight (Fig. 2). In North America, adult anadromous sea lampreys averaged nearly $20-\mathrm{cm}$ shorter $(66 \mathrm{~cm})$ in the East Machias River, Maine (Davis 1967) and nearly $15 \mathrm{~cm}$ shorter in the Connecticut River $(71 \mathrm{~cm})$, St. John $(72 \mathrm{~cm})$ River, and New Brunswick Rivers (Beamish and Potter 1975; Stier and Kynard 1986) than in Portugal. In the Laurentian Great Lakes, adult sea lampreys are even smaller, and averaged only $48 \mathrm{~cm}$ in $\mathrm{TL}(\mathrm{SD}=4.5 \mathrm{~cm})$ over all lakes (Fig. 3), with small variation among lakes Superior $(44 \mathrm{~cm} ; \mathrm{SD}=4.2 \mathrm{~cm})$, Huron $(48 \mathrm{~cm} ; \mathrm{SD}=3.9 \mathrm{~cm})$, Michigan $(49 \mathrm{~cm} ; \quad \mathrm{SD}=3.8 \mathrm{~cm})$, Erie $(51 \mathrm{~cm}$; $\mathrm{SD}=4.2 \mathrm{~cm})$, and Ontario $(49 \mathrm{~cm} ; \mathrm{SD}=4.4 \mathrm{~cm})$.

Fecundity of landlocked sea lampreys, measured as the number of eggs per gram of body weight, ranged from $339 \mathrm{eggs} / \mathrm{g}$ for Lake Ontario populations (O'Connor 2001) to $670 \mathrm{eggs} / \mathrm{g}$ for a Lake Superior population (Manion 1972). This measure of relative fecundity depends on when gravid females are collected, because adult sea lampreys stop feeding, so females collected later in the spawning run expended more energy and body mass searching for mates and building nests. Consequently, wet weight is lower late in the spawning run, so the ratio of eggs to gram of body mass increases (Manion 1972). Absolute fecundity is proportional to sea lamprey size, so larger sea lampreys in Great Lakes with warmer water (Michigan, Erie, and Ontario) are more fecund than in Great Lakes with colder water (Superior and Huron, Sullivan and Adair 2014). Absolute fecundity is also related to diet quality, so female sea lampreys are more fecund in Lake Superior (67,000 eggs/female), with a

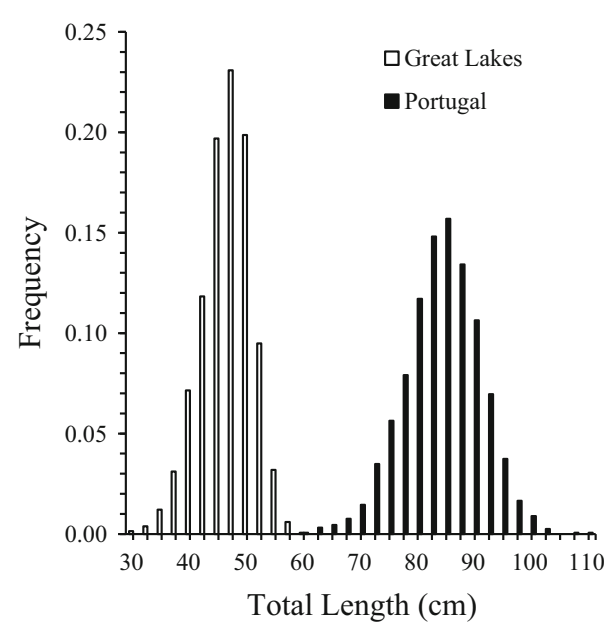

Fig. 3 Length-frequency distributions of adult sea lampreys caught during upstream spawning migrations in streams throughout the Laurentian Great Lakes basin, North America, 2000-2015 ( $\mathrm{N}=50,348$; USFWS and DFO unpublished data), and in Europe (Portugal) in rivers Minho, Lima, Cávado, Douro, Vouga, Mondego, Tagus and Guadiana, 2000-2014 (N = 1580; Quintella et al. 2003)

large population of lake trout, than in Lake Huron (46,000 eggs/female) or Cayuga Lake (43,000 eggs/ female), with fewer preferred prey (Manion 1972). This difference in absolute fecundity among lakes may be lower since the 1960s, because sea lamprey control continued to suppress sea lamprey populations while host populations increased (Heinrich et al. 1980).

In the Laurentian Great Lakes, lake-wide adult sea lamprey abundance has been a primary metric used to evaluate success of the bi-national sea lamprey control program since the late 1970 s and early 1980s. Lakewide estimates are generated by summing estimates of adult sea lamprey abundance from tributaries that sea lampreys use for spawning. In streams with traps, stream-specific estimates are generated using markrecapture or measures of trap efficiency. Estimates for streams without traps are generated using a model that incorporates five independent variables (Mullett et al. 2003). Since the onset of sea lamprey control in the Great Lakes, lake-wide estimates of adult sea lamprey abundance ranged from 261,000 in 1981 to 12,000 in 1994 in Lake Superior, 169,000 in 2004 to 29,000 in 1997 in Lake Michigan, 450,000 in 1993 to 42,000 in 1997 in Lake Huron, 33,000 in 2009 to 1700 in 2002 in Lake Erie, and 297,000 in 1982 to 23,000 in 1994 in Lake Ontario. 
In Europe, abundance of the anadromous sea lamprey has rarely been measured or monitored, although abundance and exploitation of the population in the Garonne River basin in France, a river with one of the largest populations and fisheries for the species in Europe, have been estimated (Beaulaton et al. 2008). The average catch of sea lampreys from the Garonne basin was $72 \mathrm{t}$ ( 67,000 individuals) during 1985-2003. Abundance, estimated using a generalized linear model (GLM) of catch per unit of effort (CPUE) during 1943-2000, peaked at 10-15 kg/day (weighted average) in 1957-1965. From 1973 through the 1990s, abundance was stable at 35-40\% of the maximum in 1957-1965. Since the end of the 1990s, abundance increased, and by 2000, reached abundance levels last observed in the 1960s. Portuguese rivers also support large populations of sea lampreys, but lack of good records from annual catches makes accurate estimation of population abundance difficult for most rivers. In the River Minho, northern Portugal, official records of landings dating back to 1914 show an increase in the number of sea lampreys caught by professional fisherman, with a peak in 2009 of about 60,000 specimens (Mota 2014). For the River Mondego, central Portugal, a professional fisheries survey in 2014 enabled an estimate of annual harvest of 30,000 individuals and a total estimate of 100,000 individuals that entered the river during the spawning migration (ICES 2014).

\section{Reproduction}

Physical factors essential for successful reproduction include steady, unidirectional water flow, and suitable sand and gravel (0.9-5.1 cm diameter) substrates, water velocity $(0.5-1.5 \mathrm{~m} / \mathrm{s})$, depth $(13-170 \mathrm{~cm})$, and temperature (10.0-26.1 ${ }^{\circ} \mathrm{C}$ ) (Manion and Hanson 1980). Nest building begins when water temperature warms to $\sim 15{ }^{\circ} \mathrm{C}$ (Applegate 1950). Nest construction is usually initiated by males, but females may initiate nest construction near the end of the spawning season when numerically dominant. Nest construction takes 1-3 days, with activity increasing after females join males (Applegate 1950). Mature spermiated males release a potent sex pheromone that induces preference and searching behavior in ovulated females ascending to upstream spawning areas (Li et al. 2002). On average, spawning lasts $\sim 2-5 \mathrm{~s}$ and is repeated every 4-5 min (see Johnson et al. 2015a, b for a thorough review of spawning behavior). Spawning activity is typically monogamous (Applegate 1950; Manion and McLain 1971; Hanson and Manion 1978, 1980), although polyandry may increase when the adult sex ratio is skewed away from 1:1 (Hanson and Manion 1978, 1980). Genetic evidence suggests that both polyandry and polygyny are widespread (Scribner and Jones 2002). In the upper Great Lakes, each female produces an average of $\sim 60,000$ eggs, and fertilization and survival of eggs in the nest can be as great as $90 \%$ (Manion and Hanson 1980). Egg development depends on temperature (Piavis 1961) and hatching success typically averages only $\sim 6.3 \%$ (Manion 1968). After eggs incubate for about 2 weeks, pro-larvae emerge from the nest at night over a period of several weeks and range 5-12 $\mathrm{mm}$ in length (Applegate 1950; Derosier et al. 2007).

\section{Larval life stage}

After hatching, blind, poor-swimming larvae are carried downstream from nests to depositional areas of sand, silt, and detritus, where they burrow into soft sediments to feed on suspended organic matter (Sutton and Bowen 1994; Dawson et al. 2015). Dispersal from nests is highly variable and is influenced by larval density and water temperature (Derosier et al. 2007). Age-0 larvae can remain within a few hundred meters of the nest in their first year of life (Manion and McLain 1971), or they may move downstream after emerging to reduce density-dependent effects on recruitment (Derosier et al. 2007). Although larval sea lampreys seldom leave their burrows, some larvae move downstream spontaneously in response to hydrologic conditions or at night (Hardisty and Potter 1971a, b). Downstream movement is stimulated more in streams with higher gradient, particularly during periods of high water discharge (Quintella et al. 2005), which may lead to the observation of larger (older) larvae in the lower reaches of some streams where spawning habitat is limited (Hardisty and Potter 1971a, b; Quintella et al. 2003). Redistribution of larvae over short distances may result in burrowing in more suitable habitat (Hardisty and Potter 1971a, b; Yap and Bowen 2003). Depth of the burrow is directly correlated with lamprey size (Hardisty and Potter 1971a). Habitat selection, indexed as larval density, is 
correlated with water velocity and substrate hardness (Thomas 1962). Age-1-and-older larvae are also known to migrate from silty substrates to locations with coarser substrates in summer, presumably as temperature increases and oxygen concentration declines in depositional areas (Sullivan 2003). Larvae are sensitive to light, and withdraw into burrows during daytime. Larvae remain burrowed for 3-5 years on average, and filter-feed on seston, diatoms, and biofilm (Sutton and Bowen 1994; Quintella et al. 2003). Larvae are able to move upstream against relatively slow currents $(<0.2 \mathrm{~m} / \mathrm{s})$ (Quintella et al. 2005).

Overlap in habitat among lamprey species may lead to interspecific competition that affects survival and growth of sea lamprey larvae (Beamish and Lowartz 1996). For example, Northern brook lamprey (Ichthyomyzon fossor) select habitats that leads to higherquality diet (Yap and Bowen 2003), and consequently, they may compete with sea lamprey larvae for resources. Year-class strength is driven by both density-independent and density-dependent forces, so environmental variation plays a large role in determining year-class strength that is not explained by adult abundance (Jones et al. 2003; Dawson 2007; Dawson and Jones 2009). Density-independent recruitment variation leads to occasionally strong year classes of larvae even when adult abundance is low (Jones et al. 2003). Strong year classes can be produced by adult density as low as 1.0 female/ $100 \mathrm{~m}^{2}$ of larval habitat, but evidently not at adult density sizes below 0.2 females $/ 100 \mathrm{~m}^{2}$ (Dawson and Jones 2009). Therefore, control programs could aim to reduce adult female density to fewer than 0.2 females/ $100 \mathrm{~m}^{2}$ of suitable nursery habitat for recruits, and conversely, recovery programs could seek to increase adult female density to more than 0.2 females $/ 100 \mathrm{~m}^{2}$ of nursery habitat for recruits.

Typical larval habitat is protected from major fluctuations in water levels or stream flow, where current velocity is slow. Such conditions are often found in eddies or backwaters at bends in a river, where soft silt and sand accumulate to provide suitable substrate for burrowing larvae (Table 1). Such habitat is often partially shaded, so diatoms often encrust the interface between silt and water, thereby contributing to stability of such microenvironments (Hardisty 1979). Most importantly, existence of suitable conditions for larval colonization depends on stream gradients that determine overall current velocity, the size of deposited substrate particles, and accumulation of organic debris (Hardisty and Potter 1971a). Suitable river substrate is essential for development of larval lampreys, to enable burrow construction and to maintain water flow (Hardisty 1979; Kainua and Valtonen 1980; Malmqvist 1980; Morman et al. 1980; Potter 1980; Young et al. 1990a, b; Kelso and Todd 1993; Beamish and Jebbink 1994; Ojutkangas et al. 1995; Beamish and Lowartz 1996; Sugiyama and Goto 2002; Goodwin et al. 2008). Larvae depend on unidirectional water flow through their branchial chamber, to provide detritus food and to exchange respiratory gases and metabolic wastes (Hardisty and Potter 1971a). Small larvae (20-60 mm TL) prefer small-grained substrate (silt-sand), medium-sized larvae (60-140 mm TL) prefer medium-grained substrate (gravel-silt-sand), and large larvae (140-200 mm TL) prefer coarsegrained sediments (gravelly-sand and sand) (Almeida and Quintella 2002; Sullivan 2003; Table 4). Small

Table 1 Habitat variables important for larval sea lamprey at different spatial scales (adapted from Dawson et al. 2015)

\begin{tabular}{lll}
\hline Variables & Study type & Source \\
\hline Substrate (medium-fine sand) & Laboratory & Lee (1989) \\
Substrate (sand) & Field & Young et al. (1990a) \\
Substrate (silt-sand) & Field & Young et al. (1990b) \\
Substrate (sand) & Field & Almeida and Quintella (2002) \\
Substrate/distance from stream mouth/slope of the lake bottom & Field & Fodale et al. (2003) \\
Substrate (sand/fine organic matter) & Field & Slade et al. (2003) \\
Geomorphic features (river slope - radius of curvature) & Field & Neeson et al. (2008) \\
Substrate (fine-medium sand)/water depth $(>2 \mathrm{~m}) /$ current (slow)/macrophyte roots & Field & Taverny et al. (2012) \\
\hline
\end{tabular}

${ }^{a}$ Lentic habitat 
larvae are often found in fine-grained sediments, likely because soft sediments allow young larvae with reduced swimming capacity to propel their head and branchial region into the substrate (Quintella et al. 2007). In contrast, large larvae colonize a wider range of sediments because their ability to burrow is considerably higher (Quintella et al. 2007), and because they have had a greater amount of time to colonize multiple habitats (Sullivan et al. 2008). Because selection of sediment is size-dependent, differences in preference for distinct sediment types within the same age group may have resulted from larval redistribution at the end of each annual growing season, perhaps as a strategy to avoid high density in areas colonized by younger individuals to reduce intraspecific competition for space and food (Almeida and Quintella 2002). Larval distribution is also associated with slow current, although sediment particle size is strongly determined by current velocity, thereby confounding the relative importance of current and substrate particle size in determining larval distribution (Young et al. 1990b; Almeida and Quintella 2002).

Small-scale studies of larval lamprey habitat have been useful for developing a general understanding of the biology of lampreys. However, conservation and management of lamprey populations requires the ability to evaluate and predict spatial patterns in larval abundance at several scales (Torgersen and Close 2004). The evaluation of ecological patterns and processes at multiple scales may reveal causal factors that are important at one scale, but are less important or have an opposite effect at other scales (Torgersen and Close 2004). Studies of lamprey ecology in streams and rivers have addressed the interplay of macro- and micro-environmental factors as influences on larval distribution (Baxter 1957; Hardisty and Potter 1971a, b). Broad-scale distribution patterns of larval lampreys, including the juxtaposition of adult spawning habitat upstream of larval habitat, is related to variation in channel gradient within and among streams (Baxter 1957; Young et al. 1990a). For example, larval sea lamprey density varies longitudinally with channel gradient, and the influence of channel gradient on larval density increases with spatial scale (Torgersen and Close 2004).

Larval abundance is directly linked to environmental variables, but biological factors, such as the spawning distribution of adults, also plays an important role in larval distribution (Torgersen and Close 2004). For example, larval distribution along a river is strongly associated with spawning areas, with larval density inversely related to distance downstream from spawning areas (Morman et al. 1980; Almeida and Quintella 2002; Quintella et al. 2003; Derosier et al. 2007). Similarly, adults must have access to spawning habitat, so the presence of migration barriers influences larval abundance and distribution (Goodwin et al. 2008). Last, metamorphosing lampreys are often found in the same sites where larvae of all sizes are found (Potter 1980; Quintella et al. 2003). During the initial stage of metamorphosis, transforming juveniles are relatively more sedentary than larvae (Quintella et al. 2005), whereas later on, juveniles burrow less, so are found hiding between pebbles, and under aquatic vegetation, rocks, and other structures (Dawson et al. 2015).

Prior to burrowing, larval mortality from predation is likely high (Potter 1980), although estimates of agespecific larval survival are limited by a lack of age estimates. Larval survival was $96 \%$ between age 1 and age 4 (Morman 1987), although this estimate was likely too high because caged larvae were protected from mortality (Johnson et al. 2014). In contrast, results from modeling studies have yielded estimates of much lower larval survival in streams of Lake Erie (39.5\%, Irwin et al. 2012), Lake Michigan (45\% Jones et al. 2009), and Lake Ontario (51.8 \% Irwin et al. 2012). In the St. Marys River, estimates of survival have ranged from 35-49\% (Haeseker et al. 2003) to 66-91\% (Jones et al. 2012). Variability among estimates may reflect environmental conditions or uncertainty associated with using multiple parameters to simulate the response of sea lamprey populations to management actions with management strategy evaluation (MSE) models. Regardless, the wide range of survival estimates is consistent with a large range in variation of density-independent survival (Jones et al. 2003).

Larval sea lampreys hatch at $\sim 9 \mathrm{~mm}$ in length, and growth depends on biotic and abiotic factors like population density and water temperature (Table 2; Morman 1987; Murdoch et al. 1992). In a Lake Ontario tributary, the first year class to infest a stream following lampricide treatment grew faster than subsequent year classes (Weise and Pajos 1998), which suggests growth was density dependent (Dawson et al. 2015). In the 
Table 2 Minimum, maximum, and mean lengths of sea lampreys at larval (minimum and maximum only), recently metamorphosed juvenile, feeding juvenile (minimum and maximum only), and spawning adult life stages in the
Laurentian Great Lakes (landlocked form; USFWS and DFO unpublished data) and North American and European rivers draining to the Atlantic Ocean (anadromous form; Quintella et al. 2003; doi:10.1006/jfbi.2000.1465)

\begin{tabular}{lll}
\hline Life stage & Total length $(\mathrm{mm})$ & Maximum \\
\cline { 3 - 3 } & Minimum & \\
\hline Laurentian Great Lakes_landlocked & & 196 \\
$\quad$ Larvae & 9 & 196 \\
Recently Metamorphosed Juvenile & 100 & 639 \\
Feeding Juvenile & 100 & 624 \\
Spawning Adult & 49 & 200 \\
Europe-anadromous & & 188 \\
Larvae & 9 & - \\
Recently Metamorphosed Juvenile & 105 & 1113 \\
Feeding Juvenile & - & 477 \\
Spawning Adult & 607 & 149 \\
\hline
\end{tabular}

River Mondego, Portugal, larval sea lampreys averaged $59 \mathrm{~mm}$ in TL (range $=53-74 \mathrm{~mm}$ ) at age $0+$ ( $<9$ months post-hatch), $95 \mathrm{~mm}$ in TL (range $=58-144 \mathrm{~mm})$ at age $1+(9-21$ months posthatch), $140 \mathrm{~mm}$ in TL (range $=93-179 \mathrm{~mm}$ ) at age $2+$ (21-33 months post-hatch), $166 \mathrm{~mm}$ in TL (range $=142-190 \mathrm{~mm})$ at age $3+(33-45$ months posthatch), and $184 \mathrm{~mm}$ in TL (range $=179-188 \mathrm{~mm}$ ) at age 4+ ( $>45$ months post-hatch; Quintella et al. 2003). Larval growth is nearly $0 \mathrm{~mm}$ in some years, and some individuals may stay 1 year in a river to accumulate fat needed to metamorphose (i.e. sometimes termed the "retarded growth phase"). Larvae from the River Mondego, Portugal, had shorter larval stage duration (Quintella et al. 2003) than in more northerly river basins, such as anadromous populations in Canada (range $=6-8$ years; Beamish and Potter 1975) and Great Britain (average $=5$ years; Hardisty 1969a, b), likely because higher productivity associated with warmer water enhances feeding efficiency and growth (Morman 1987). As expected for a poikilothermic organism, growth of sea lamprey larvae is correlated with water temperature (Potts et al. 2015), and varies among geographic regions with different climatic conditions, with faster growth in more favorable climates (Potter 1980; Dawson et al. 2015).

Age estimation of sea lamprey larvae, particularly in controlled populations, initially relied on analysis of length-frequency data (Table 3) but can be supplemented by knowing the number of years since known recruitment (Weise and Pajos 1998; Hansen et al. 2003; Dawson et al. 2015). However, growth rates vary greatly within and among cohorts within stream populations, so age cannot be accurately assigned from length-frequency histograms (Dawson et al. 2009), especially for older age classes (Hardisty and Potter 1971a; Hardisty 1979). Statoliths, like otoliths in teleosts, are calcium carbonate structures that accumulate annuli for use in age estimation of sea lampreys (Volk 1986; Hollett 1998; Henson et al. 2003). Although statolith-based age estimates may be biased for sea lamprey larvae (Dawson et al. 2009), accurate estimates of age can be obtained by combining length-frequency information with a sample of bias-corrected statolith-based age in a statistical model of larval growth. Statolith-based age estimation is not reliable for populations that do not form cohesive statoliths (Barker et al. 1997) or for larvae that resorb statoliths (Lochet et al. 2013). In addition, age estimates vary greatly among readers (Dawson et al. 2009).

Although analysis of length-frequency distributions and statolith readings are the only method for estimating larval sea lamprey age, growth rate can be estimated with other methods, such as in situ cages (c.f. Malmqvist 1983; Morman 1987; Zerrenner 2004), laboratory growth experiments (c.f. Murdoch et al. 1992; Rodriguez-Muñoz et al. 2003), release of adult spawners into naturally inaccessible streams or stream reaches (Dawson et al. 2009), and surveys 
within lampricide-treated streams in years following treatment (Griffiths et al. 2001). Use of in situ cages and laboratory methods to measure larval growth rate have been useful for assessing effects of factors such as density (Malmqvist 1983; Mallatt 1983; Morman 1987; Murdoch et al. 1992; Rodriguez-Muñoz et al. 2003; Zerrenner 2004) and temperature (Mallatt 1983; Holmes 1990; Rodríguez-Muñoz et al. 2001). Most such studies confirmed that larval growth was inversely related to larval density (Malmqvist 1983; Morman 1987; Murdoch et al. 1992; RodriguezMuñoz et al. 2003), although one study of larvae held for 1 year in $0.16-\mathrm{m}^{2}$ circular cages suggested larval growth was independent of density (Zerrenner 2004). In the Great Lakes, larval sea lampreys are present in streams where winter water temperatures near $0{ }^{\circ} \mathrm{C}$ (USFWS and DFO unpublished data). Growth was highest in streams with mean annual water temperature of $\sim 8{ }^{\circ} \mathrm{C}$, discharge of $0.5-2.0 \mathrm{~m}^{3} / \mathrm{s}$, and $>300 \mu \mathrm{S}$ conductivity (Griffiths et al. 2001) and larvae reach a maximum length of $196 \mathrm{~mm}$ in total length (Table 1). In Europe, $8{ }^{\circ} \mathrm{C}$ is close to the minimum temperature where the sea lamprey is present, and growth is highest in systems with higher average temperatures, with some larvae attaining $190 \mathrm{~mm}$ in total length (Quintella et al. 2003).

Gonadogenesis in larval sea lampreys usually begins when larvae are 40-60 mm TL and ages 1-2 and gonadal differentiation is usually complete when larvae are 90-100 mm TL and ages 3-4 (Hardisty 1969a; Docker 1992; Wicks et al. 1998). Biotic and abiotic factors are thought to contribute to sex determination in lamprey species, such as larval density, temperature, $\mathrm{pH}$, and when physiological resources are diverted into somatic growth, although mechanisms are not well established (Hardisty 1965a, b; Barker et al. 1998; Neave 2004; Dawson et al. 2015). In Great Lakes sea lamprey populations, selection pressure from pesticide application is implicated in sex determination (Smith 1971; Heinrich et al. 1980; Wicks et al. 1998). For example, males predominated in high pre-control sea lamprey populations (Smith 1971), with $70 \%$ males in Lake Superior and $68 \%$ males in lakes Huron and Michigan, whereas sex ratios shifted toward females after years of treatment, with only $28 \%$ males in Lake Superior and $21 \%$ males in Lake Michigan (Heinrich et al. 1980). A similar shift in the sex ratio in Lake Huron began before treatment reduced larval density, and was as low as $31 \%$ males by 1975 , likely because of environmental conditions and extremely low abundance of lake trout in the 1950s (Purvis 1979; Heinrich et al. 1980). Contemporary sex ratios have typically been $50-70 \%$ males in the Great Lakes (Fig. 4), although the increase in the proportion of males in Lake Erie in 2007 and 2008 corresponds to recordhigh abundance of adult lampreys in those years, despite consecutive years treating sea lamprey producing streams in 2008-2009 and 2009-2010. In French rivers, the sex ratio favors females for both exploited and unexploited rivers (Beaulaton et al. 2008). For North American anadromous sea lamprey populations, males typically outnumber females (Beamish 1980). Estimates of adult sex ratio are fraught with uncertainty, depending on sampling time and methods (see Johnson et al. 2015a, b).

Abundance of larval sea lampreys was estimated in most Great Lakes tributaries during 1995-2013 using quantitative assessment methods, which were generally greater than those estimated by mark-recapture (Slade et al. 2003; Hansen and Jones 2008; Dawson et al. 2015). Stream-specific estimates of abundance ranged from less than 50 to more than 6-million larvae. Larval abundance has also been estimated in small to mid-sized tributaries using mark-recapture techniques, with estimates ranging from 3,000 to nearly 2-million larvae (Steeves 2002; Hansen and Jones 2008). Estimates of maximum larval abundance in

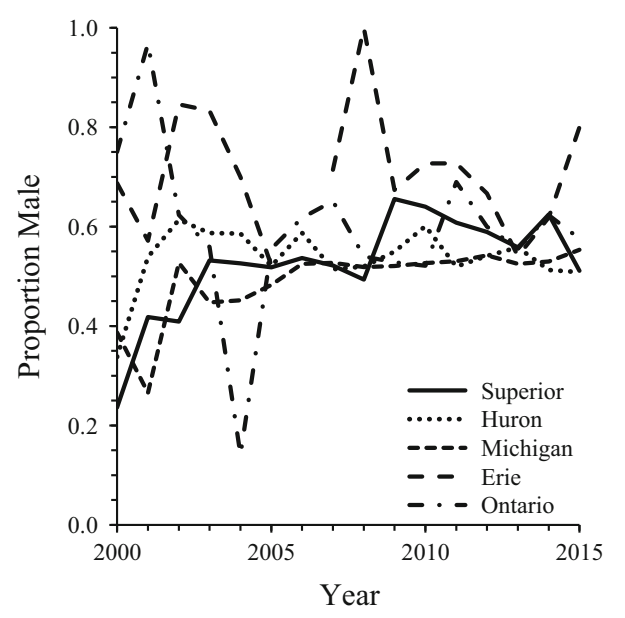

Fig. 4 Proportion of adult male sea lampreys caught during upstream spawning migrations in streams throughout the Laurentian Great Lakes basin, North America, 2000-2015 $(\mathrm{N}=50,348$; USFWS and DFO unpublished data) 
Great Lakes tributaries currently infested with larval sea lampreys suggest that these streams are capable of producing nearly 69 million larvae, with 2.7 million in Lake Superior, 15 million in Lake Michigan, 22 million in Lake Huron, 0.5 million in Lake Erie, and 4.5 million in Lake Ontario.

\section{Metamorphosis}

In spring of the year of metamorphosis, larvae are usually 3-5 years old, and are at least 100-mm long in the Great Lakes and 120-mm long in Europe (average $=130-140 \mathrm{~mm}$; Table 1; Dawson et al. 2015). Larvae metamorphose into juveniles by development of an oral disk, appearance of teeth, eruption of eyes, enlargement of fins, and changes in pigmentation (Hardisty and Potter 1971b), all of which enable transformed individuals to change from sedentary larvae filter-feeding in streams to free-swimming predators in marine or lake environments (Manion and Stauffer 1970; Youson et al. 1977; Potter and Beamish 1977; Youson 1980; Hardisty 2006). Metamorphosis depends on length and weight, and particularly, on accumulation of lipids as energy stores, because the sea lamprey does not feed during metamorphosis (Holmes and Youson 1994; Youson 2003; Treble et al. 2008). Metamorphosis generally commences in July with changes to internal organs and body proportions, and concludes by September (Potter and Beamish 1977). Larval sea lampreys were once thought to transfer somatic growth strictly to mass and accumulation of lipids in the year of metamorphosis (Potter 1980), but recent data suggest that larvae also change in total length prior to metamorphosis (Hollett 1998; Treble et al. 2008). Age at metamorphosis is primarily related to growth and accumulation of lipid stores in larvae (Youson 1980; Treble et al. 2008), and inversely related to latitude, with larvae in southern streams growing faster than in northern streams (Hansen et al. 2003; Treble et al. 2008; Quintella et al. 2003). In cold untreated streams, larvae may not metamorphose until age ten or more, as in the St. Marys River (Haeseker et al. 2003) or the Big Garlic River (Manion and McLain 1971; Manion and Smith 1978). Sea lampreys then migrate from a stream, typically during high water events in autumn or spring (Applegate 1950), and begin the parasitic stage of life in an ocean or lake environment.

\section{Juvenile life stage}

Downstream migration of juveniles is triggered by increasing stream flow (Potter 1980; Bird et al. 1994; Hardisty 2006) that coincides with peak stream flows in autumn and spring in the Great Lakes (Applegate 1950; Potter 1980). Numbers of downstream migrating juveniles are usually greater in autumn than spring in the Great Lakes (Applegate and Brynildson 1952; Applegate 1961; Hodges 1972; Potter and Huggins 1973; Potter 1980; Hanson and Swink 1989; Swink and Johnson 2014). Downstream migration begins as early as September and ends as late as mid- to lateApril or early-May, and is predominantly at night, with out-migrating juveniles burrowing into substrates or hiding beneath cover during the day (Applegate 1950, 1961; Hanson and Swink 1989; Swink and Johnson 2014). For anadromous populations in Europe, downstream migration is from late autumn through early winter (Taverny and Elie 2009), although movement is between October and May, with a peak in March, in the Galician region of northwestern Spain (Silva et al. 2013a, b). In Western Europe, milder weather may lead to a more continuous and gradual downstream migration than in the Great Lakes region of North America (Silva et al. 2013a, b). Timing of downstream migration was markedly bimodal in North American sea lamprey populations (landlocked and anadromous populations entering Canadian Atlantic Rivers) in autumn and spring (Applegate 1950; Hardisty 2006). This bimodal distribution, typical for North American populations, is not followed by European anadromous populations, which typically migrate with progressively increasing number of individuals moving toward a peak in March, although peak movement varies annually (Silva et al. 2013b). The spatial distribution of outmigrating juveniles in the water column is believed to be greatest in the thalweg near the surface where current velocity is greatest.

Survival of juvenile sea lampreys is poorly understood, but is likely related to factors associated with conditions in natal streams when juveniles out-migrate and availability of hosts in lake or ocean environments near natal streams when juveniles begin to feed (Young et al. 1990a). In lakes Michigan and Huron, mark-recapture studies indicated that survival of outmigrating juveniles to migratory adult stage was highly variable and was as high as $90 \%$ (Sullivan 
Table 3 Duration of the sea lamprey larval life stage (methods listed are those used to estimate age and growth; adapted from Dawson et al. 2015)

\begin{tabular}{lll}
\hline Larval stage (years) & Method & Source \\
\hline $3.4-3.9$ & Length-frequency & Applegate (1950) \\
5 & Length-frequency & Hardisty (1969) \\
6 & Length-frequency & Lowe et al. (1973) \\
$6-8$ & Length-frequency & Beamish and Potter (1975) \\
$5-12$ & Known recruitment date & Manion and Smith (1978) \\
5 & Length-frequency & Hardisty (1979) \\
$3-7$ & Length-frequency & Purvis (1979) \\
5 & Cage & Morman (1987) \\
2 & Length-frequency/statolith & Morkert et al. (1998) \\
$3-4$ & statolith & Griffiths et al. (2001) \\
4 & Length-frequency/statolith & Quintella et al. (2003) \\
\hline
\end{tabular}

and Adair 2010). Survival did not differ between autumn and spring juveniles of three parasitic cohorts that were tagged and released while out-migrating and recovered as adults 12-18 months later (Swink and Johnson 2014). Therefore, the opportunity for fall migrants to feed over winter did not improve survival.

Little is known about the marine life-history phase of anadromous sea lampreys (Beamish 1980; Halliday 1991), whereas studies of the landlocked form to estimate the duration of the parasitic phase using diverse methods suggest a juvenile parasitic stage of $\sim 1$ year (Table 4) or about 18-20 months between completion of metamorphosis and reproduction. Similarly, a mark-recapture study suggests a period of 18-20 months between completion of metamorphosis and reproduction in the Galician River, northwest Spain, where 408 sea lampreys were captured and tagged with external T-bar anchor tags at the onset of feeding (Silva et al. 2013a, b).

Growth of juvenile sea lampreys increases with the onset of sexual maturity (Bergstedt and Swink 1995), where mass increases linearly from June through September, but more sharply in October (Madenjian et al. 2003). Growth of juvenile sea lampreys is also greater at higher temperatures, as is mortality of host fish following sea lamprey attack (Swink 2003; Farmer et al. 1977). However, the observed increase in growth during October was not associated with an increase in water temperature, but rather, may have been due to an increased likelihood of attaching to a host and actively feeding on host blood during October (Madenjian et al. 2003). Models of juvenile sea lamprey growth in Lake Superior indicate that sea lampreys can reach spawning size within 12 months even in the coldest temperature regimes (Moody et al. 2011). The effect of climate change is expected to increase the range of thermal habitat, and subsequently, the growth rate and attained size of sea lampreys (Cline et al. 2013). Juvenile sea lamprey grew 227-268 $\mathrm{g}$ in weight in one summer, from outmigration in autumn and spring 1998-2000 (initial weight $=5.33-6.01 \mathrm{~g}$ ) to recapture in spring 1 year later, in the Black Mallard Creek, Michigan, a tributary to Lake Huron (Swink and Johnson 2014). In the Galician River, Spain, one lamprey grew from $218 \mathrm{~mm}$ in total length and $20 \mathrm{~g}$ in weight when tagged to $895 \mathrm{~mm}$ in total length and $1218 \mathrm{~g}$ in weight 13.5 months later when recaptured during its spawning migration into the same river (Silva et al. 2013a, b).

The period between final metamorphosis (OctoberNovember) and downstream migration can extend up to 3-4 months in European rivers, so sea lampreys may start feeding in freshwater streams after metamorphosis is complete (Potter and Beamish 1977; Beamish 1980; Silva et al. 2013a, b). For example, small juvenile sea lampreys were attached to resident brown trout Salmo trutta in a Spanish river (Silva et al. 2013a, b), which corroborates observations of North American populations for which $10-30 \%$ of metamorphosed juveniles started feeding in rivers before migrating downstream (Davis 1967; Potter and Beamish 1977). The golden grey mullet Liza aurata (Risso, 1810), is an important and very abundant prey species in lower parts of European estuaries (Silva 
Table 4 Duration of the sea lamprey juvenile and adult life stage (methods listed are those use to determine duration)

\begin{tabular}{llll}
\hline $\begin{array}{l}\text { Juvenile and adult stage } \\
\text { (years) }\end{array}$ & Ecotype/population & Method & Source \\
\hline $1-1.7$ & Landlocked & Captures at Great Lakes & Applegate (1950) \\
$2-2.5$ & $\begin{array}{l}\text { Anadromous/North } \\
\text { America }\end{array}$ & Captures at sea & Beamish (1980) \\
1.5 & $\begin{array}{l}\text { Anadromous/North } \\
\text { America }\end{array}$ & Captures at sea & Halliday (1991) \\
1 & $\begin{array}{l}\text { Landlocked } \\
1.5-1.7\end{array}$ & Captures at Great Lakes/Mark- & Bergstedt and Swink \\
& Anadromous/Europe & Mark-recapture & Silva et al. (2013a, b) \\
\hline
\end{tabular}

${ }^{a}$ Period between completion of metamorphosis (completion of stage 7 and prior to outmigration) and reproduction

et al. 2013a, b). In rivers Mondego and Tagus, Portugal, thin-lipped grey mullets (Liza ramada, Risso, 1827) are also commonly observed with wounds from sea lamprey juveniles (Almeida, unpublished data). Large schools of mullets in European estuaries (Almeida 1996) may constitute an easy prey during this last phase of adaptation to the marine environment (Almeida and Quintella 2013). Juvenile lampreys have limited swimming capacities (Dauble et al. 2006), so predation on an intermediate species that is moving to the sea may increase survival of young sea lampreys during initial parasitic feeding in predator-rich marine environments.

Abundance of out-migrating juvenile sea lampreys estimated using mark-recapture methods ranged widely in Lake Huron $(536,000-1,100,000)$ and in Lake Michigan (325,000-813,000; Sullivan and Adair 2010; Young et al. 2003). Young et al. (2003) concluded that these mark-recapture methods likely overestimated abundance of out-migrating sea lampreys. For example, mark-recapture estimates of the abundance of five cohorts of out-migrating juveniles $(639,000-803,000)$ were larger on average than those of five cohorts of feeding juveniles (515,000-2,342,000), likely because tagging and handling mortality was higher for feeding juveniles than for out-migrating juveniles (Bergstedt et al. 2003). In the absence of control, these estimates of juvenile sea lamprey abundance for controlled populations would have been much greater.

\section{Feeding}

A bioenergetics model for the sea lamprey by Kitchell and Breck (1980) was developed from laboratory studies of standard metabolism (Beamish 1973), blood consumption (Farmer et al. 1975), egestion and excretion (Farmer et al. 1975), and the effect of water temperature on sea lamprey growth (Farmer et al. 1977). Sea lampreys used in laboratory experiments by Beamish (1973) showed very little, if any, movement within the respiration chamber, and therefore these respiration rate measurements were categorized as standard metabolic rates (SMRs). However, the energy budget of sea lampreys from the Laurentian Great Lakes would not balance based on respiration that only included SMR, so Kitchell and Breck (1980) hypothesized that sea lampreys must exhibit some activity and multiplied SMR by an activity multiplier $(\mathrm{ACT}=1.5)$ to balance the energy budget. Recent underwater video of sea lampreys attached to lake trout in Lake Champlain confirms that sea lampreys swim even when attached to hosts (E. Marsden, University of Vermont, personal communication; Madenjian et al. 2013).

Size-based interactions between individual sea lampreys and individual lake trout, the preferred host in the Laurentian Great Lakes, appeared to be important factors affecting mortality inflicted by sea lampreys on lake trout, so individual-based models (IBMs) have been applied to Great Lakes sea lamprey populations (MacKay 1992; Madenjian et al. 2003). Feeding models for the sea lamprey were based on laboratory studies in which sea lamprey growth was measured during the time of attachment to a host, and then fitted to observed growth to estimate sea lamprey feeding rate with the sea lamprey bioenergetics model (Cochran and Kitchell 1989; Cochran et al. 1999). Bioenergetics and feeding models were incorporated into IBMs to estimate blood consumption and sea 
lamprey-induced mortality on lake trout by a sea lamprey population. Results indicated that sea lamprey growth, blood consumption by sea lampreys, and sea lamprey-induced mortality on lake trout peaked in October and November. The incidence of fresh wounds by sea lamprey on lake trout should therefore peak in October-November. Application of the sea lamprey bioenergetics model to sea lamprey in Lake Ontario confirmed that growth and blood consumption by sea lampreys peaked in autumn, which suggests that sea lamprey-induced mortality on hosts should peak in autumn (Kitchell and Breck 1980).

Recent comparisons of contaminant concentrations between male and female adult sea lampreys from northern Lake Huron suggested that males expended energy at a faster rate than females, because of higher swimming activity and possibly higher SMR (Madenjian et al. 2013, 2014). Mercury (Hg) and polychlorinated biphenyls (PCBs) have both been used as tracers of food consumption by fish, and male sea lampreys were 16-17\% higher in $\mathrm{Hg}$ and $\mathrm{PCB}$ concentrations than female sea lampreys, which suggests males fed at a 16-17\% higher rate than females. Higher swimming activity by adult male sea lampreys than adult female sea lampreys has been documented in the laboratory (Madenjian et al. 2013).

\section{Effects on host species}

Interactions between sea lampreys and their hosts in the Great Lakes are well-described by a Type- 2 functional response in the attack rate and a development response in the growth rate (Bence et al. 2003). A Type-2 functional response assumes that the sea lamprey attack rate on a host increases with host density to a maximum attack rate at which the sea lamprey population is satiated by prey density. Similarly, a developmental response assumes that sea lamprey growth increases with host density to a maximum growth rate at which sea lamprey growth is satiated by host density. Sea lamprey populations in the Great Lakes do not exhibit numerical responses in either attack or growth rates, but rather, survival from metamorphosis to the summer-autumn period is assumed to be constant $(S=0.5$ ) for parasitic-phase animals (Bence et al. 2003). However, survival of young parasites, as well as older parasites, is variable and partially depends on host density and also perhaps on water temperature (Christie and Kolenosky 1980; Eshenroder et al. 1995; Swink 1995).

Host selection is influenced by host size, with sea lampreys preferring to attack larger hosts (Cochran and Kitchell 1989; Bence et al. 2003; Swink 2003). Moreover, the lake trout is the preferred host of sea lampreys in the Great Lakes (Christie and Kolenosky 1980; Johnson and Anderson 1980; Bence et al. 2003; Morse et al. 2003; Harvey et al. 2008), although ciscoes (Coregonus spp.) are preferred by small ( $<15$ g) sea lampreys (Johnson and Anderson 1980; Harvey et al. 2008). Sea lampreys may change their selectivity for hosts, perhaps in response to changing host abundance (Bence et al. 2003). For example, sea lamprey wounding on lake whitefish (Coregonus clupeaformis) was lower than wounding on lake trout when lake trout were abundant, whereas wounding on lake whitefish increased when lake trout were scarce. Similarly, wounding of large Chinook salmon (Oncorhynchus tshawytscha) was relatively high when lake trout abundance was low in northern Lake Huron. Based on stable-isotope signatures of sea lampreys and their prey in six regions of Lake Superior, sea lampreys fed predominantly on lake trout across the lake, but fed heavily on Coregonus spp. and Catostomus spp. in Black Bay, where these alternate hosts were more abundant than lake trout (Harvey et al. 2008).

Lethality of a sea lamprey attack on host species is a key determinant of sea lamprey-induced mortality on a host species' population (Bence et al. 2003), but available estimates vary widely and those based on tank studies may have been biased by confinement stress. Estimates of lethality of a sea lamprey attack on lake trout vary from nearly $0 \%$ (negligible lethality) to $82 \%$, and mortality from a sea lamprey attack was higher $(64 \%)$ for small lake trout (469-557 mm TL) than for medium (44\%; 559-643 mm TL) and large (43\%; 660-799 mm TL) lake trout in laboratory tanks (Swink 2003). However, stress from confinement in relatively small ( $151 \mathrm{~L}$ in volume) tanks may have contributed additional mortality in these laboratory experiments. Lake sturgeon (Acipenser fulvescens) similar in size to young adult lake trout survived sea lamprey attacks at a higher rate $(70 \%)$ in larger ( $>1000$ L) tanks (Patrick et al. 2009), perhaps because lake sturgeon have tougher skin than lake trout. Further, $66-74 \%$ of adult lake trout survived sea lamprey attacks based on field data from Lake 
Champlain, Lake Ontario, and Lake Huron (Madenjian et al. 2008a). In contrast, the lethality of a sea lamprey attack on age-3 to age-5 lake whitefish was $75 \%$, based on a mark-recapture study in Lake Huron (Spangler et al. 1980), lethality of sea lamprey attacks on lake whitefish should be substantially higher than on lake trout because adult lake trout are substantially larger than adult lake whitefish. Similarly, lethality of sea lamprey attacks on adult burbot (Lota lota) should be higher than on adult lake trout.

Sea lampreys are capable of contributing substantially to declining abundance of host populations in aquatic ecosystems they invade. For example, predation by sea lamprey, along with overfishing, were responsible for collapses of lake trout populations in lakes Superior, Michigan, and Huron in the 1940s and 1950s (Hansen 1999). Lake trout abundance was already declining in each of these three lakes from overfishing in the early $1900 \mathrm{~s}$, but sea lamprey invasion in the 1930s accelerated rates of declining lake trout abundances in each lake in the 1940s and 1950s (Hansen 1999). In the 1960s, sea lamprey control in conjunction with intensive stocking enabled a buildup of lake trout populations in the 1970s and 1980s in the upper Great Lakes, and widespread natural reproduction by lake trout in Lake Superior. Further, sea lamprey predation contributed to declining abundance of lake whitefish in the upper Great Lakes in the 1950s (Lawrie and Rahrer 1972; Berst and Spangler 1973; Wells and McLain 1973), after which sea lamprey control contributed to recovery of lake whitefish populations (Madenjian et al. 2008b). Sea lamprey predation has also been suspected of having some effect on abundance of coregonines other than lake whitefish in the upper Great Lakes (Lawrie and Raher 1972; Berst and Spangler 1973; Wells and McLain 1973). Last, sea lamprey predation contributed to declining burbot abundance in the upper Great Lakes in the 1950s (Berst and Spangler 1973; Wells and McLain 1973; Gorman and Sitar 2013), after which sea lamprey control enabled recovery of burbot populations in the Laurentian Great Lakes (Madenjian et al. 2008b; Stapanian et al. 2008).

Even with reduced sea lamprey populations due to control activities, sea lamprey predation is still a large source of mortality on host populations in the Laurentian Great Lakes. For example, sea lamprey predation was the predominant source of mortality experienced by the lake trout population in Lake Huron during
1984-1993 (Sitar et al. 1999). More recently, sea lamprey predation is still believed to be an important source of mortality on lake whitefish populations in northern Lake Huron (M. Ebener, Chippewa Ottawa Resource Authority, personal communication). Of course, accuracy of these estimates of sea lampreyinduced mortality depend on accuracy of estimates of sea lamprey attack lethality. In addition to predation effects, sea lamprey attacks on hosts can also lead to sub-lethal effects. For example, lake sturgeon that survived a sea lamprey attack suffered acute anemia (Sepúlveda et al. 2012). Similarly, immune function was reduced and lipid stores were depleted in lake trout surviving sea lamprey attacks (Smith 2013). Longterm influences of such sub-lethal effects on host population dynamics have not been quantified.

\section{Future status}

How will climate change affect sea lamprey population ecology in the Laurentian Great Lakes and Europe?

Global climate change has been identified as a driver of change in thermal habitat of fish species that would increase biomass of sea lampreys in Lake Superior (Moody et al. 2011). Forecasts of increased fecundity and sea lamprey induced mortality are expected to negatively impact native fish species, particularly siscowet lake trout in Lake Superior (Cline et al. 2013). Global climate change is expected to increase negative effects of sea lamprey-induced mortality on host fish populations in Lake Superior, one of the most rapidly warming lakes on Earth (Kitchell et al. 2014). As Lake Superior continues to warm, sea lamprey growth is predicted to increase, thereby producing larger sea lampreys, greater blood consumption by sea lampreys, and increased lethality of sea lamprey attacks on hosts (Cline et al. 2014; Kitchell et al. 2014). Further, climate change may cause longer feeding seasons, increased growth, and larger sea lampreys (Cline et al. 2013), with increased fecundity, particularly in Lake Superior (Moody et al. 2011), which may lead to increased sea lamprey abundance. Climate change is also predicted to increase the magnitude of flood events that could lead to reduced effectiveness of low-head barriers used to block upstream spawning migrations of sea lampreys in the 
Great Lakes (Rahel and Olden 2008). The impact of climate change on the geographic distribution of sea lampreys in the Great Lakes is unknown, but changes in water levels, discharge, and temperature are likely to result in variation in streams selected for spawning, with varying impacts on larval recruitment and growth. In total, global climate change will likely require additional effort to maintain the current level of control of sea lampreys in the Great Lakes.

Global climate change is expected to greatly alter the geographic distribution of the sea lamprey in Europe (Lassalle et al. 2008). Specifically, the presence of sea lampreys in basins bordering the east coast of the Adriatic Sea, most Italian basins, and in the Iberian Peninsula (including Spain and Portugal) is expected to decrease in the future, based on predictions of precipitation and water temperature in tributaries. In the northern part of the species' range, conditions would likely remain suitable and waters in Iceland could even become suitable for the sea lamprey (Lassalle et al. 2008; Maitland et al. 2015). In Southwestern Europe, the sea lamprey is economically valuable, and supports commercial fisheries in major river systems, but is vulnerable to reductions in suitable essential habitats. Conservation measures to rehabilitate sea lamprey habitat and to manage for sustained commercial exploitation have been proposed (Almeida and Quintella 2002; Andrade et al. 2007). Further, conservation plans for sea lamprey should include projections of the geographic distribution of the sea lamprey in response to global climate change, with priority given to restoring suitable basins in Portugal (Lassalle et al. 2008).

Which attributes of sea lamprey population ecology can be used to control populations in the Laurentian Great Lakes?

\section{Adult}

Migratory habits of adult sea lampreys are currently being exploited by using barriers to block upstream migration and traps to capture and remove upstream migrating adults in Great Lakes tributaries (McLaughlin et al. 2007). Nonetheless, increased knowledge of adult sea lamprey movement and barrier design will be crucial to effective control (McLaughlin et al. 2007). Further, current barrier technology limits passage of non-jumping fishes, so new barrier designs must enable fish passage (McLaughlin et al. 2007).
Trapping of adult sea lampreys is presently not used for control, but could be important if trapping efficacy is improved and the number of spawning adults is reduced enough to minimize larval recruitment (McLaughlin et al. 2007). Therefore, development of new trap designs that exploit ecological and behavioral aspects of adult migration, such as staging behavior at river mouths or movements within streams, while minimizing by-catch of other species, would benefit future control (Bravener and McLaughlin 2013). Use of attractants or repellents may increase trap efficacy, thereby reducing adult abundance and larval recruitment, or reducing infested areas of streams by making them less desirable for migrating or spawning adults (Johnson et al. 2015). Enhanced barrier design and more effective trapping can also reduce reliance on chemical use (McLaughlin et al. 2007).

\section{Larval}

The sedentary life habits that last 2-5 years appears to be the critical ecological attribute for control at this life stage. Current control depends on reducing recruitment of juvenile sea lampreys to the Great Lakes by killing larvae during their sedentary life stage with strategic applications of lampricides every 2-4 years, depending upon larval recruitment and growth. Further exploitation of this life stage should be explored, by developing new lampricides to further reduce or eliminate larval populations, or autocidal technologies (Thresher 2008) to manipulate genes that slow growth, determine sex, prohibit metamorphosis, or increase larval mortality by disrupting feeding behavior (McCauley et al. 2015). Last, because larvae spend multiple years in the same stream environment, they acquire regionally unique chemical signatures that identify their general natal origin (Hand et al. 2008). Refining methods to determine the specific stream of origin of larvae that survive or are not exposed to lampricide applications would be beneficial for targeting future control.

\section{Juvenile}

Success of sea lamprey control in the Great Lakes depends on the ability to apply pesticides to natal streams prior to sea lamprey metamorphosis and migration. Research has attempted to identify factors controlling metamorphosis (Docker et al. 2003), such 
as endocrinology (Youson 1994; Youson et al. 1994; Youson 1999), environmental conditions such as temperature (Purvis 1980; Youson 2003), conspecific density (Purvis 1980; Morman 1987; Treble et al. 2008), and gender distortion (Thresher et al. 2014). Recent sequencing of the sea lamprey genome may provide control opportunities if genes that regulate metamorphosis can be exploited (Smith et al. 2013; McCauley et al. 2015). Further, downstream migration of juveniles is a stage in the sea lamprey life history that is not presently exploited for control, but holds promise for the future (Johnson and Miehls 2014). Because out-migration of juveniles typically occurs at night during protracted periods of high discharge, efforts to trap this life stage are costly and have met with limited success. However, this life stage of sea lamprey ecology represents the last opportunity to remove this pest before it inflicts damage on host fishes. Development of new trapping technologies or guidance systems to lead out-migrating juveniles into traps or areas where survival can be reduced may result in more effective methods for exploiting this stage of the sea lamprey life history.

Future research on sea lamprey bioenergetics and feeding should focus on sea lamprey feeding rates, feeding models, and sex-specific bioenergetics models. Weight-specific feeding rates of sea lampreys in summer did not significantly change as sea lamprey weight increased from 20 to $160 \mathrm{~g}$ (Farmer et al. (1975), but weight-specific consumption rates may substantially decrease as lamprey body weight increases from 160 to $400 \mathrm{~g}$ and may also be influenced by seasonal cues (Madenjian et al. 2003). Attachment time is also suspected to be influenced by sea lamprey size, host size, and water temperature. Sex-specific bioenergetics models will require SMR and swimming activity to be determined for male and female juvenile (parasitic-phase) sea lampreys at various sizes, water temperatures, and times of the year, and would, for example, be useful for modeling how climate change would affect population fecundity and predation effects on host species.

Which attributes of sea lamprey population ecology can be used to restore and conserve populations in Europe?

An absence of genetic differences among sea lamprey populations within western Atlantic (Waldman et al.
2008) and eastern Atlantic rivers suggests regional panmixia with reproductively isolated European and North American sea lamprey populations (RodríguezMuñoz et al. 2004; Bryan et al. 2005; Genner et al. 2012). Nevertheless, recent studies in Portugal suggested the existence of a population structure composed of three different stocks (North/Central, Tagus and Guadiana) possibly promoted by sea bed topography (Lança et al. 2014). The hypothesis of a limited dispersion capacity in the ocean raises questions about management and conservation of this species in Europe, because oceanic regions and specific watersheds likely play an important role in the conservation of sea lamprey populations in southwestern Europe. Sea bed topography could play a major role in dispersion of sea lampreys from natal streams, thereby causing dispersion to differ between European and North American Atlantic coasts. Such differences are particularly important in areas where the species presents conservation challenges, because success of any management plan implemented to sustain the species' fisheries depends on sound understanding of the species life cycle (Almeida and Quintella 2013). More research on this subject is warranted, to guide future restoration and management of the species in Europe.

Because of its decline across Europe, the sea lamprey was given some legal protection (Lelek 1987; Renaud 1997; Mateus et al. 2012) under Annex II of the European Union Habitats Directive, Appendix III of the Bern Convention, and in the OSPAR (OsloParis) convention list (Convention for the Protection of the Marine Environment of the North- east Atlantic). Aquatic pollution, and habitat fragmentation and reduction caused by construction of large dams, weirs, and other man-made barriers, are among the greatest threats to European sea lamprey population (Gardner et al. 2012; Mateus et al. 2012; Hogg et al. 2013; Rooney et al. 2015; Maitland et al. 2015). Since the late twentieth century, sea lamprey populations have increased slightly following improvement of water quality in some European rivers (Beaulaton et al. 2008). The sea lamprey is presently assessed as Least Concern in the European Red List of Freshwater Fishes (Freyhof and Brooks 2011), although it is considered threatened in Red List categories of several European countries (Mateus et al. 2012). Recovery of sea lamprey populations in Europe will depend mostly on restoration of freshwater habitat and on promoting 
sustainable management of commercial exploitation in both estuarine and freshwater environments. Lack of reliable records of commercial harvest from each river basin where this species occurs is a major drawback that introduces subjectivity and risk to fishery management.

Pheromones are crucial for the sea lampreys' lifehistory that could potentially be useful as management tools for both control programs in the Great Lakes and conservation programs in Europe. The sea lamprey produces at least two types of pheromones. Streamdwelling larvae release a migratory bile acid-based pheromone that guides adult sea lampreys to watersheds that were successful as spawning and nursery areas for larvae (Bjerselius et al. 2000). Mature spermiated male sea lampreys also release a potent sex pheromone that induces preference and searching behavior by ovulated female lampreys ascending to upstream spawning areas (Li et al. 2002). The bile acid pheromone released by larvae may be used to attract adults to rivers where habitat was restored, thereby increasing speed of recolonization. Male sex pheromone may be used to increase the efficiency of fish passage devices by increasing attractiveness of a fish passage entrance.

Which attributes of sea lamprey population ecology are useful for both control programs in the Great Lakes and restoration programs in Europe?

Many of the same features of sea lamprey population ecology that are useful for control programs in the Great Lakes of North America are also useful for restoration programs in Europe. For example, migration by adult sea lampreys into streams to spawn has been exploited since the late 1940s as a population control strategy by blocking upstream migration with traps and barriers (McLaughlin et al. 2007). Nontarget effects of traps and barriers on species other than the sea lamprey have been the focus of research and engineering aimed to enable passage of non-target species while simultaneously blocking passage of sea lampreys (McLaughlin et al. 2007). Not surprisingly, dams on rivers in Europe are presently one of the primary factors limiting sea lamprey access to spawning areas upstream (Mateus et al. 2012). We propose that understanding of how to block adult sea lamprey passage in streams for control purposes in the Great
Lakes is also useful for allowing passage of adult sea lampreys for restoration purposes in Europe and elsewhere where the species is imperiled (Moser et al. 2015). For example, traps within fish ladders to sort and remove adult sea lampreys in Great Lakes streams would be useful designs for traps within fish ladders to catch and transport adult sea lampreys to European streams free from dams (McLaughlin et al. 2007). Similarly, use of attractants and repellants to lure sea lampreys into physical or ecological traps for their control in the Great Lakes would be equally useful for luring sea lampreys into traps and fishways for their conservation (e.g. to guide their passage around or through barriers) where they are imperiled in their native range ( $\mathrm{Li}$ et al. 2007).

The long period of life spent in streams by larval and juvenile sea lampreys that makes the species vulnerable to pesticide control in the Great Lakes also provides a focus for habitat protection, mitigation, and enhancement where the species is imperiled in Europe and elsewhere. Since 1958, sea lamprey control in the Great Lakes targeted the stream-dwelling non-parasitic larval phase of the sea lamprey life history, because larvae are relatively sedentary and live for several years in streams (McDonald and Kolar 2007). Pesticide control of sea lamprey populations in the Great Lakes was subsequently directed by assessments of the abundance and distribution of larval sea lampreys within and among streams, including assessment of the suitability of instream habitat (Hansen et al. 2003; Jones 2007). These same assessment methods for targeting sea lamprey control in the Great Lakes are equally useful for targeting habitat protection, mitigation, and enhancement of sea lamprey populations where they are imperiled in their native range. Similarly, assessment methods for juvenile and adult sea lampreys that aim to enhance effectiveness of control in the Great Lakes (e.g. migration timing, mating systems, and factors influencing spawning success, Jones 2007) would be useful for enhancing effectiveness of conservation measures where the species is imperiled in its native range. Assessment methods presently used for measuring success of sea lamprey control in the Great Lakes (e.g. quantifying numbers of all life stages, Jones 2007) would be equally useful for measuring success of sea lamprey conservation elsewhere in its native range. 
Which attributes of sea lamprey population ecology are in need of further study for management of the species worldwide?

Much has been learned about sea lamprey population dynamics, but some areas of sea lamprey population dynamics require further study, especially in relation to abundance, survival, recruitment, and feeding. For example, abundance of the sea lamprey in Europe has rarely been measured or monitored (except for the population in the Garonne River, France; Beaulaton et al. 2008), but is crucial for understanding the population status of the species. Methods by which juvenile and adult sea lamprey abundance is monitored in the Laurentian Great Lakes may be useful models for European population monitoring (e.g. Hansen et al. 2003; Jones 2007). Similarly, little is known about the marine phase of anadromous sea lampreys, especially habitat and host preferences, dynamics and mechanisms of movement, although much has now been learned about how adults locate freshwater spawning streams and mates with streams using pheromones (e.g. Bjerselius et al. 2000; Li et al. 2002; Silva et al. 2013a). Research into the effects of pheromones in the different spatial and chemical scales of the marine environment may provide management tools applicable to the regional stocks of anadromous sea lampreys. Telemetry (acoustic and archival) may be useful for increasing knowledge of movement by feeding-phase sea lampreys in the Atlantic Ocean and Great Lakes (e.g. Johnson et al. 2015a, b). Movement of out-migrating juveniles is only generally understood, so is an area of fruitful future study (e.g. Johnson and Miehls 2014). Recruitment is highly dynamic, because of the interplay of strong density-independent and density-dependent forces, but must be studied more broadly in both native and introduced populations, to better understand general patterns of recruitment dynamics. As a general subject of study, dynamics of survival and mortality of sea lampreys is poorly understood for all life stages, including adults, larvae, recently metamorphosed juveniles, and feeding juveniles. Feeding dynamics of sea lamprey have benefited from bioenergetics studies, but more research is needed on feeding rates, feeding models, and sex-specific bioenergetics models (e.g. Madenjian et al. 2003). Last, long-term sub-lethal effects of feeding-phase sea lampreys on host populations should be studied, to improve understanding of effects of invasive nonnative sea lampreys in the Laurentian Great Lakes.

Acknowledgments We thank Erin Dunlop, Ontario Ministry of Natural Resources, and four anonymous reviewers for their many helpful comments on the manuscript. Use of trade, product, or firm names is for descriptive purposes and does not imply endorsement by the U.S. Government. The findings and conclusions in this article are those of the authors and do not necessarily represent the views of the U.S. Fish and Wildlife Service. This article is Contribution 2031 of the U.S. Geological Survey, Great Lakes Science Center.

Open Access This article is distributed under the terms of the Creative Commons Attribution 4.0 International License (http:// creativecommons.org/licenses/by/4.0/), which permits unrestricted use, distribution, and reproduction in any medium, provided you give appropriate credit to the original author(s) and the source, provide a link to the Creative Commons license, and indicate if changes were made.

\section{References}

Adair R, Sullivan P (2013) Sea lamprey control in the Great Lakes 2012. Great Lakes Fishery Commission, Annual Report, May 29-30, 2013, Ann Arbor, Michigan

Almeida PR (1996) Biologia e Ecologia de Liza ramada (Risso, 1826) e Chelon labrosus (Risso, 1826) (Pisces, Mugilidae) no Estuário do Mira (Portugal). Inter-relações com o Ecossistema Estuarino. $\mathrm{PhD}$ dissertation, University of Lisbon, Portugal

Almeida PR, Quintella BR (2002) Larval habitat of the sea lamprey (Petromyzon marinus L.) in the river Mondego (Portugal). In: Collares-Pereira MJ, Coelho MM, Cowx IG (eds) Freshwater fish conservation: options for the future. Blackwell Science, Oxford, pp 121-130

Almeida PR, Quintella BR (2013) Sea Lamprey migration: a millenial journey. In: Ueda $\mathrm{H}$, Tsukamoto K (eds) Physiology and ecology of fish migration. CRC Press, Boca Raton, pp 105-131

Almeida PR, Silva HT, Quintella BR (2000) The migratory behaviour of the sea lamprey Petromyzon marinus L., observed by acoustic telemetry in the River Mondego (Portugal). In: Moore A, Russel I (eds) Advances in fish telemetry. CEFAS, Lowestoft, pp 99-108

Almeida PR, Quintella BR, Dias NM (2002a) Movement of radio-tagged anadromous sea lamprey during the spawning migration in the River Mondego (Portugal). Hydrobiologia 483:1-8

Almeida PR, Quintella BR, Dias NM, Andrade N (2002b) The anadromous sea lamprey in Portugal: biology and conservation perspectives. In: Moser M, Bayer J, MacKinlay D (eds) The biology of lampreys, symposium proceedings, International Congress on the Biology of Fish, American Fisheries Society, 21-25 July, Vancouver, British Columbia, pp 49-58 
Andrade NO, Quintella BR, Ferreira J, Pinela S, Póvoa I, Sílvia P, Almeida PR (2007) Sea lamprey (Petromyzon marinus L.) spawning migration in the Vouga river basin (Portugal): poaching impact, preferential resting sites and spawning grounds. Hydrobiologia 582:121-132

Applegate VC (1950) Natural history of the sea lamprey (Petromyzon marinus) in Michigan. US Fish Wildl Serv Spec Sci Rep Fish 55, Washington, DC

Applegate VC (1961) Downstream movement of lampreys and fishes in the Carp Lake River, Michigan. US Fish Wildl Serv Spec Sci Rep Fish 387, Washington, DC

Applegate VC, Brynildson C (1952) Downstream movement of recently transformed sea lampreys, Petromyzon marinus, in the Carp Lake River, Michigan. Trans Am Fish Soc 81:275-290

Applegate VC, Smith BR (1951) Movement and dispersion of a blocked spawning run of sea lampreys in the Great Lakes. Trans N Am Wildl Conf 16:243-351

Barker LA, Morrison BJ, Wicks BJ, Beamish FWH (1997) Age discrimination and statolith diversity in sea lamprey from streams with varying alkalinity. Trans Am Fish Soc 126:1021-1026

Barker LA, Morrison BJ, Wicks BJ, Beamish FWH (1998) Potential fecundity of landlocked sea lamprey larvae, Petromyzon marinus, with typical and atypical gonads. Copeia 1998:1070-1075

Bartels H, Potter IC (2007) Cellular composition and ultrastructure of the gill epithelium of larval and adult lampreys: implications for osmoregulation in fresh and seawater. J Exp Biol 207:3447-3462

Baxter EW (1957) Lamprey distribution in streams and rivers. Nature 180:1145

Beamish FWH (1973) Oxygen consumption of adult Petromyzon marinus in relation to body weight and temperature. J Fish Res Board Can 30:1367-1370

Beamish FWH (1978) Swimming capacity. In: Hoar WS, Randall DJ (eds) Fish physiology, vol VII. Academic Press, New York, pp 101-187

Beamish FWH (1980) Biology of the North American anadromous sea lamprey, Petromyzon marinus. Can J Fish Aquat Sci 37:1924-1943

Beamish FWH, Jebbink J (1994) Abundance of lamprey larvae and physical habitat. Environ Biol Fish 39:209-214

Beamish FWH, Lowartz S (1996) Larval habitat of American brook lamprey. Can J Fish Aquat Sci 53:693-700

Beamish FWH, Potter IC (1975) The biology of the anadromous sea lamprey (Petromyzon marinus) in New Brunswick. J Zool 177:57-72

Beaulaton L, Taverny C, Castelnaud G (2008) Fishing, abundance and life history traits of the anadromous sea lamprey (Petromyzon marinus) in Europe. Fish Res 92:90-101

Becker GC (1983) Fishes of Wisconsin. University of Wisconsin Press, Madison

Bence JR, Bergstedt RA, Christie GC, Cochran PA, Ebener MP, Koonce JF, Rutter MA, Swink WD (2003) Sea lamprey (Petromyzon marinus) parasite-host interactions in the Great Lakes. J Great Lakes Res 29(Suppl 1):253-282

Bergstedt RA, Seelye JG (1995) Evidence for lack of homing by sea lampreys. Trans Am Fish Soc 124:235-239

Bergstedt RA, Swink WD (1995) Seasonal growth and duration of the parasitic life stage of the landlocked sea lamprey
(Petromyzon marinus). Can J Fish Aquat Sci 52:1257-1264

Bergstedt RA, McDonald RB, Mullett KM, Wright GM, Swink WD, Burnham KP (2003) Mark-recapture population estimates of parasitic sea lampreys (Petromyzon marinus) in Lake Huron. J Great Lakes Res 29(Suppl 1):226-239

Berst AH, Spangler GR (1973) Lake Huron-The ecology of the fish community and man's effects on it. Great Lakes Fishery Commission, Technical Report 21, Ann Arbor, Michigan

Bigelow HB, Schroeder WC (1948) Fishes of the western North Atlantic, part 1, cyclostomes. Mem Sears Found Mar Res 1:29-58

Binder TR, McLaughlin RL, McDonald DG (2010) Relative importance of water temperature, water level, and lunar cycle to migratory activity in spawning phase sea lampreys in Lake Ontario. Trans Am Fish Soc 139:700-712

Bird DJ, Potter IC, Hardisty MW, Baker BI (1994) Morphology, body size and behaviour of recently-metamorphosed sea lampreys, Petromyzon marinus, from the lower River Severn, and their relevance to the onset of parasitic feeding. J Fish Biol 44:67-74

Bjerselius R, Li W, Teeter JH, Seelye JG, Johnsen PB, Maniak PJ, Grant GC, Polkinghorne CN, Sorensen PW (2000) Direct behavioral evidence that unique bile acids released by larval sea lamprey function as a migratory pheromone. Can J Fish Aquat Sci 57:557-569

Bravener GA, McLaughlin RL (2013) A behavioural framework for trapping success and its application to invasive sea lamprey. Can J Fish Aquat Sci 70:1438-1446

Bryan MB, Zalinski D, Filcek KB, Libants S, Li W, Scribner KT (2005) Patterns of invasion and colonization of the sea lamprey (Petromyzon marinus) in North America as revealed by microsatellite genotypes. Mol Ecol 14:3757-3773

Christie GL, Goddard CI (2003) Sea lamprey international symposium (SLIS II): advances in the integrated management of sea lamprey in the Great Lakes. J Great Lakes Res 29(Suppl 1):1-14

Christie WJ, Kolenosky DP (1980) Parasitic phase of the sea lamprey (Petromyzon marinus) in Lake Ontario. Can J Fish Aquat Sci 37:2021-2038

Cline TJ, Bennington V, Kitchell JF (2013) Climate change expands the spatial extent and duration of preferred thermal habitat for Lake Superior fishes. PLoS ONE 8(4):e62279. doi:10.1371/journal.pone.0062279

Cline TJ, Kitchell JF, Bennington V, McKinley GA, Moody EK, Weidel BC (2014) Climate impacts on landlocked sea lamprey: implications for host-parasite interactions and invasive species management. Ecosphere 5:68

Cochran PA, Kitchell JF (1989) A model of feeding by parasitic lampreys. Can J Fish Aquat Sci 46:1845-1852

Cochran PA, Swink WD, Kinziger AP (1999) Testing and extension of a sea lamprey feeding model. Trans Am Fish Soc 128:403-413

Dauble DD, Moursund RA, Bleich MD (2006) Swimming behaviour of juvenile Pacific lamprey, Lampetra tridentata. Environ Biol Fish 75:167-171

Davis RM (1967) Parasitism by newly-transformed anadromous sea lampreys on landlocked salmon and other fishes in a coastal Maine lake. Trans Am Fish Soc 96:11-16 
Dawson HA (2007) Recruitment dynamics of Great Lakes sea lamprey (Petromyzon marinus) populations and implications for integrated pest management. $\mathrm{PhD}$ dissertation, Michigan State University, East Lansing

Dawson HA, Jones ML (2009) Factors affecting recruitment dynamics of Great Lakes sea lamprey (Petromyzon marinus) populations. J Great Lakes Res 35:353-360

Dawson HA, Jones ML, Scribner KT, Gilmore SA (2009) An assessment of age determination methods for Great Lakes larval sea lampreys. N Am J Fish Manage 29:914-927

Dawson HA, Quintella BR, Almeida PR, Treble AJ, Jolley JC (2015) The ecology of larval and metamorphosing lampreys. In: Docker MF (ed) Lampreys: biology, conservation and control. Springer, Berlin, pp 75-137

Derosier AL, Jones ML, Scribner KT (2007) Dispersal of sea lamprey larvae during early life: relevance for recruitment dynamics. Environ Biol Fish 78:271-284

Docker MF (1992) Labile sex determination in lampreys: the effect of larval density and sex steroids on gonadal differentiation. PhD dissertation, University of Guelph

Dolinsek IJ, McLaughlin RL, Grant JW, O'Connor LM, Pratt TC (2014) Do natural history data predict the movement ecology of fishes in Lake Ontario streams? Can J Fish Aquat Sci 71:1171-1185

Eddy S, Underhill JC (1974) Northern fishes, with special reference to the Upper Mississippi Valley, 3rd edn. University of Minnesota Press, Minneapolis

Emery L (1985) Review of fish introduced into the Great Lakes, 1819-1974. Great Lakes Fishery Commission, Technical Report 45, Ann Arbor, Michigan

Eshenroder RL (2014) The role of the Champlain canal and Erie canal as putative corridors for colonization of Lake Champlain and Lake Ontario by sea lampreys. Trans Am Fish Soc 143:634-649

Eshenroder RL, Payne NR, Johnson JE, Bowen C II, Ebener MP (1995) Lake trout rehabilitation in Lake Huron. J Great Lakes Res 21(Supplement 1):108-127

Farmer GJ, Beamish FWH, Robinson GA (1975) Food consumption of the adult landlocked sea lamprey, Petromyzon marinus, L. Comp Biochem Physiol 50A:753-757

Farmer GJ, Beamish FWH, Lett PF (1977) Influence of water temperature on the growth rate of landlocked sea lamprey (Petromyzon marinus) and the associated rate of host mortality. J Fish Res Board Can 34:1373-1378

Fodale MF, Bronte CR, Bergstedt RA, Cuddy DW, Adams JV (2003) Classification of lentic habitat for sea lamprey (Petromyzon marinus) larvae using a remote seabed classification device. J Great Lakes Res 29(Suppl 1):190-203

Freyhof J, Brooks E (2011) European red list of freshwater fishes. Publications Office of the European Union, Luxembourg

Gardner C, Coghlan SM Jr, Zydlewski J (2012) Distribution and abundance of anadromous sea lamprey spawners in a fragmented stream: current status and potential range expansion following barrier removal. Northeast Nat 19:99-110

Genner MJ, Hillman R, McHugh M, Hawkins SJ, Lucas MC (2012) Contrasting demographic histories of European and North American sea lamprey (Petromyzon marinus) populations inferred from mitochondrial DNA sequence variation. Mar Freshw Res 63:827-833
Gerking SD (1955) Key to the fishes of Indiana. Investig Indiana Lakes Streams 4:49-86

Goodwin CE, Dick JTA, Rogowski DL, Elwood RW (2008) Lamprey (Lampetra fluviatilis and Lampetra planeri) ammocoete habitat associations at regional, catchment and microhabitat scales in Northern Ireland. Ecol Freshw Fish 17:542-553

Gorman OT, Sitar SP (2013) Ups and downs of burbot and their predator lake trout in Lake Superior, 1953-2011. Trans Am Fish Soc 142:1757-1772

Griffiths RW, Beamish FWH, Morrison BJ, Barker LA (2001) Factors affecting larval sea lamprey growth and length at metamorphosis in lampricide-treated streams. Trans Am Fish Soc 130:289-306

Gross M (1987) The evolution of diadromy in fishes. Am Fish Soc Symp 1:14-25

Haeseker SL, Jones ML, Bence JR (2003) Estimating uncertainty in the stock-recruitment relationship for St. Marys River sea lampreys. J Great Lakes Res 29(Suppl. 1):728-741

Halliday RG (1991) Marine distribution of the sea lamprey (Petromyzon marinus) in the northwest Atlantic. Can J Fish Aquat Sci 48:832-842

Hand CP, Ludsin SA, Fryer BJ, Marsden EJ (2008) Statolith microchemistry as a technique for discriminating among Great Lakes sea lamprey (Petromyzon marinus) spawning tributaries. Can J Fish Aquat Sci 65:1153-1164

Hansen MJ (1999) Lake trout in the Great Lakes: basinwide stock collapse and binational restoration. In: Taylor WW, Ferreri CP (eds) Great Lakes fisheries policy and management: a binational perspective. Michigan State University Press, East Lansing, pp 417-453

Hansen GJA, Jones ML (2008) A rapid assessment approach to prioritizing streams for control of Great Lakes sea lampreys: a case study in adaptive management. Can J Fish Aquat Sci 65:2471-2484

Hansen MJ, Adams JV, Cuddy DW, Doemel JM, Fodale MF, Larson GL, Ollila DJ, Slade JW, Steeves TB, Young RJ, Zerrenner A (2003) Optimizing larval assessment to support sea lamprey control in the Great Lakes. J Great Lakes Res 29(Suppl 1):766-782

Hanson LH, Manion PJ (1978) Chemosterilization of the sea lamprey Petromyzon marinus. Great Lakes Fishery Commission, Technical Report 29, Ann Arbor, Michigan

Hanson LH, Manion PJ (1980) Sterility method of pest control and its potential role in an integrated sea lamprey (Petromyzon marinus) control program. Can J Fish Aquat Sci 37:2108-2117

Hanson LH, Swink WD (1989) Downstream migration of recently metamorphosed sea lampreys in the Ocqueoc River, Michigan, before and after treatment with lampricides. N Am J Fish Manage 9:327-331

Hardisty MW (1965a) Sex differentiation and gonadogenesis in lampreys I, the ammocoete gonads of the brook lamprey, Lampetra planeri. J Zool 146:305-345

Hardisty MW (1965b) Sex differentiation and gonadogenesis in lampreys II, the ammocoete gonads of the landlocked sea lamprey, Petromyzon rnarinus. J Zool 146:346-387

Hardisty MW (1969a) A comparison of the gonadal development in the ammocoetes of the landlocked and anadromous 
forms of the sea lamprey, Petromyzon marinus L. J Fish Biol 2:153-166

Hardisty MW (1969b) Information on the growth of the ammocoete larva of the anadromous sea lamprey, Petromyzon marinus in British rivers. J Zool 159:139-144

Hardisty MW (1979) Biology of the cyclostomes. Chapman \& Hall, London

Hardisty MW (1986) Petromyzon marinus Linnaeus, 1758. In: Holčík J (ed) The freshwater fishes of Europe, vol 1, part 1, Petromyzontiformes. AULA-Verlag, Wiesbaden, pp 96-116

Hardisty MW (2006) Lampreys: life without jaws. Forrest Text, Ceredigion

Hardisty MW, Potter IC (1971a) The behaviour, ecology and growth of larval lampreys. In: Hardisty MW, Potter IC (eds) The biology of lampreys, vol I. Academic Press, London, pp 85-125

Hardisty MW, Potter IC (1971b) The general biology of adult lampreys. In: Hardisty MW, Potter IC (eds) The biology of lampreys. Academic Press, London, pp 127-205

Haro A, Kynard B (1997) Video evaluation of passage efficiency of American shad and sea lamprey in a modified Ice Harbor fishway. N Am J Fish Manag 17:981-987

Harvey CJ, Ebener MP, White CK (2008) Spatial and ontogenetic variability of sea lamprey diets in Lake Superior. J Great Lakes Res 34:434-449

Heinrich JW, Weise JG, Smith BR (1980) Changes in biological characteristics of the sea lamprey (Petromyzon marinus) as related to lamprey abundance, prey abundance, and sea lamprey control. Can J Fish Aquat Sci 37:1861-1871

Henson MP, Bergstedt RA, Adams JV (2003) Comparison of spring measures of length, weight, and condition factor for predicting metamorphosis in two populations of sea lamprey (Petromyzon marinus) larvae. J Great Lakes Res 29(Suppl 1):204-214

Hodges JW (1972) Downstream migration of recently transformed sea lampreys before and after treatment of a Lake Michigan tributary with a lampricide. J Fish Res Board Can 29:1237-1240

Hogg R, Coghlan SM Jr, Zydlewski J (2013) Anadromous sea lampreys recolonize a Maine coastal river tributary after dam removal. Trans Am Fish Soc 142:1381-1394

Hollett AK (1998) Condition factor and statolith aging in assessment of metamorphosis in sea lampreys (Petromyzon marinus), in the Great Lakes. MS Thesis, University of Toronto

Holmes J (1990) Sea lamprey as an early responder to climate change in the Great Lakes basin. Trans Am Fish Soc 119:292-300

Holmes J, Youson JH (1994) Fall condition factor and temperature influence the incidence of metamorphosis in sea lampreys, Petromyzon marinus. Can J Zool 72:1134-1140

ICES (2014) Report of the Workshop on Lampreys and Shads (WKLS), 27-29 November 2014, Lisbon, Portugal. ICES CM 2014/SSGEF:13, 206pp

Irwin BJ, Li W, Bence JR, Jones ML (2012) Defining economic injury levels for sea lamprey control in the Great Lakes basin. N Am J Fish Manage 32:760-771

Johnson BGH, Anderson WC (1980) Predatory-phase sea lampreys (Petromyzon marinus) in the Great Lakes. Can J Fish Aquat Sci 37:2007-2020
Johnson NS, Miehls SM (2014) Guiding out-migrating juvenile sea lamprey (Petromyzon marinus) with pulsed direct current. River Res Appl 30:1146-1156

Johnson NS, Swink DS, Brenden TO, Slade JW, Steeves TB, Fodale MF, Jones ML (2014) Survival and metamorphosis of low-density population of larval sea lampreys (Petromyzon marinus) in streams following lampricide treatment. J Great Lakes Res 40:155-163

Johnson NS, Buchinger TJ, Li W (2015a) Reproductive ecology of lampreys. In: Docker MF (ed) Lampreys: biology, conservation and control. Springer, Berlin, pp 265-303

Johnson NS, Siefkes MJ, Wagner CM, Bravener G, Steeves T, Twohey MB, Li W (2015b) Factors influencing capture of sea lamprey in traps baited with a synthesized sex pheromone component. J Chem Ecol 41:913-923

Jones ML (2007) Toward improved assessment of sea lamprey population dynamics in support of cost-effective sea lamprey management. J Great Lakes Res 33 (Special Issue 2):35-47

Jones ML, Bergstedt RA, Twohey MB, Fodale MF, Cuddy DW, Slade JW (2003) Compensatory mechanisms in Great Lakes sea lamprey populations: implications for alternative controls. J Great Lakes Res 29(Suppl 1):113-129

Jones ML, Irwin BJ, Hansen GJA, Dawson HA, Treble AJ, Li W, Dai W, Bence JR (2009) An operating model for the integrated pest management of Great Lakes sea lamprey. Open Fish Sci J 2:59-73

Jones ML, Brenden TO, Irwin BJ (2012) Evaluating integrated pest management in the St. Marys River. Great Lakes Fishery Commission, Project Completion Report, Ann Arbor, Michigan

Kainua K, Valtonen T (1980) Distribution and abundance of European river lamprey (Lampetra fluviatilis) larvae in three rivers running into Bothnian Bay, Finland. Can J Fish Aquat Sci 37:1960-1966

Kelso JR, Gardner W (2000) Emigration upstream movement and habitat use by sterile and fertile sea lampreys in three Lake Superior tributaries. N Am J Fish Manage 20:144-153

Kelso JRM, Todd PR (1993) Instream size segregation and density of Geotria australis ammocoetes in two New Zealand streams. Ecol Freshw Fish 2:108-115

Kitchell JF, Breck JE (1980) Bioenergetics model and foraging hypothesis for sea lamprey (Petromyzon marinus). Can J Fish Aquat Sci 37:2159-2168

Kitchell JF, Cline T, Bennington V, McKinley G (2014) Climate change challenges management of invasive sea lamprey in Lake Superior. In: Keller RP, Cadotte MW, Sandiford G (eds) Invasive species in a globalized world: ecological, social, and legal perspectives on policy. University of Chicago Press, Chicago, pp 209-232

Lança MJ, Machado M, Mateus CS, Lourenço M, Ferreira AF, Quintella BR, Almeida PR (2014) Investigating population structure of sea lamprey (Petromyzon marinus, L.) in western Iberian Peninsula using morphological characters and heart fatty acid signature analyses. PLoS ONE 9(9):e108110. doi:10.1371/journal.pone.0108110

Larsen LO (1980) Physiology of adult lampreys, with special regard to natural starvation, reproduction, and death after spawning. Can J Fish Aquat Sci 37:1762-1779

Lassalle G, Béguer M, Beaulaton L, Rochard E (2008) Diadromous fish conservation plans need to consider 
global warming issues: an approach using biogeographical models. Biol Conserv 141:1105-1118

Lawrie AH (1970) The sea lamprey in the Great Lakes. Trans Am Fish Soc 99:766-775

Lawrie AH, Rahrer JF (1972) Lakes Superior-A case history of the lake and its fisheries. Great Lakes Fishery Commission, Technical Report 19, Ann Arbor, Michigan

Lee DS (1989) Proximate determinants of larval lamprey habitat selection. PhD dissertation, Michigan State University, East Lansing

Lelek A (1987) The freshwater fishes of Europe. Threatened fishes of Europe, vol 9. Aula-Verlag, Wiesbaden

Li W, Scott AP, Siefkes MJ, Yan H, Liu Q, Yun S, Gage DA (2002) Bile acid secreted by male sea lamprey that acts as a sex pheromone. Science 296:138-141

Li W, Siefkes MJ, Scott AP, Teeter JH (2003) Sex pheromone communication in the sea lamprey: implications for integrated management. J Great Lakes Res 29(Suppl 1):85-94

Li W, Twohey M, Jones M, Wagner M (2007) Research to guide use of pheromones to control sea lamprey. J Great Lakes Res 33 (Special Issue 2):70-86

Lochet A, Marsden JE, Fryer BJ, Ludsin SA (2013) Instability of statolith elemental signatures revealed in newly metamorphosed sea lamprey (Petromyzon marinus). Can J Fish Aquat Sci 70:565-573

Lowe DR, Beamish FWH, Potter IC (1973) Changes in the proximate body composition of the landlocked sea lamprey Petromyzon marinus (L.) during larval life and metamorphosis. J Fish Biol 5:673-682

MacKay NA (1992) Evaluating the size effects of lampreys and their hosts: application of an individual-based model. In: DeAngelis D, Gross L (eds) Individual-based models and approaches in ecology: populations, communities, and ecosystems. Chapman and Hall, New York, pp 278-294

Madenjian CP, Cochran PA, Bergstedt RA (2003) Seasonal patterns in growth, blood consumption, and effects on hosts by parasitic-phase sea lampreys in the Great Lakes: an individual-based model approach. J Great Lakes Res 29(Suppl 1):332-346

Madenjian CP, Chipman BD, Marsden JE (2008a) New estimates of lethality of sea lamprey (Petromyzon marinus) attacks on lake trout (Salvelinus namaycush): implications for fisheries management. Can $\mathrm{J}$ Fish Aquat Sci 65:535-542

Madenjian CP, O'Gorman R, Bunnell DB, Argyle RL, Roseman EF, Warner DM, Stockwell JD, Stapanian MA (2008b) Adverse effects of alewives on Laurentian Great Lakes fish communities. N Am J Fish Manage 28:263-282

Madenjian CP, Johnson NS, Binder TR, Rediske RR, O'Keefe JP (2013) Polychlorinated biphenyl concentrations and activity of sea lamprey Petromyzon marinus vary by sex. Arch Environ Contam Toxicol 65:693-703

Madenjian CP, Johnson NS, Siefkes MJ, Dettmers JM, Blum JD, Johnson MW (2014) Mercury accumulation in sea lamprey (Petromyzon marinus) from Lake Huron. Sci Total Environ 470-471:1313-1319

Maitland PS, Renaud CB, Quintella BR, Close DA, Docker MF (2015) Conservation of native lampreys. In Lampreys: biology, conservation and control. Springer, Dordrecht, pp 376-428
Mallatt J (1983) Laboratory growth of larval lampreys (Lampetra (Entosphenus) tridentata Richardson) at different food concentrations and animal densities. J Fish Biol 22:293-301

Malmqvist B (1980) Habitat selection of larval brook lampreys (Lampetra planeri, Bloch) in a south Swedish stream. Oecologia 45:35-38

Malmqvist B (1983) Growth, dynamics, and distribution of a population of the brook lamprey Lampetra planeri in a South Swedish stream. Holarct Ecol 6:404-412

Manion PJ (1968) Production of sea lamprey larvae from nests in two Lake Superior streams. Trans Am Fish Soc 97:484-486

Manion PJ (1972) Fecundity of the sea lamprey (Petromyzon marinus) in Lake Superior. Trans Am Fish Soc 101:718-720

Manion PJ, Hanson LH (1980) Spawning behavior and fecundity of lampreys from the upper three Great Lakes. Can J Fish Aquat Sci 37:1635-1640

Manion P J, McLain AL (1971) Biology of larval sea lampreys (Petromyzon marinus) of the 1960 year class isolated in the Big Garlic River, Michigan 1960-65. Great Lakes Fishery Commission, Technical Report 16, Ann Arbor, Michigan

Manion PJ, Smith BR (1978) Biology of larval and metamorphosing sea lampreys, Petromyzon marinus, of the 1960 year class in the Big Garlic River, Michigan, Part II, 1966-72. Great Lakes Fishery Commission, Technical Report 30, Ann Arbor, Michigan

Manion PJ, Stauffer TM (1970) Metamorphosis of the landlocked sea lamprey, Petromyzon marinus. J Fish Res Board Can 27:1735-1746

Mateus CS, Rodríguez-Muñoz R, Quintella BR, Alves MJ, Almeida PR (2012) Lampreys of the Iberian Peninsula: distribution, population status and conservation. Endanger Species Res 16:183-198

McCauley DW, Docker MF, Whyard S, Li W (2015) Lampreys as diverse model organisms in the genomics era. Bioscience 65:1046-1056

McDonald DG, Kolar CS (2007) Research to guide the use of lampricides for controlling sea lamprey. J Great Lakes Res 33 (Special Issue 2):20-34

McLaughlin RL, Hallett A, Pratt TC (2007) Research to guide use of barriers, traps, and fishways to control sea lamprey. J Great Lakes Res 33 (Special Issue 2):7-19

Meckley TD, Wagner CM, Gurarie E (2014) Coastal movements of migrating sea lamprey (Petromyzon marinus) in response to a partial pheromone added to river water: implications for management of invasive populations. Can J Fish Aquat Sci 71(4):533-544

Mesa MG, Bayer JM, Seelye JG (2003) Swimming performance and physiological responses to exhaustive exercise in radio-tagged and untagged pacific lampreys. Trans Am Fish Soc 132:483-492

Moody EK, Weidel BC, Ahrenstorff TD, Mattes WP, Kitchell JF (2011) Evaluating the growth potential of sea lampreys (Petromyzon marinus) feeding on siscowet lake trout (Salvelinus namaycush) in Lake Superior. J Great Lakes Res 37:343-348

Moore HH, Schleen LP (1980) Changes in spawning runs of sea lamprey (Petromyzon marinus) in selected streams of Lake 
Superior after chemical control. Can J Fish Aquat Sci 37:1851-1860

Morkert SB, Swink WD, Seelye JG (1998) Evidence for early metamorphosis of sea lampreys in the Chippewa River, Michigan. N Am J Fish Manage 18:966-971

Morman RH (1987) Relationship of density to growth and metamorphosis of caged larval sea lampreys, Petromyzon marinus Linnaeus, in Michigan streams. J Fish Biol 30:173-181

Morman RH, Cuddy DW, Rugen PC (1980) Factors influencing the distribution of sea lamprey (Petromyzon marinus) in the Great Lakes. Can J Fish Aquat Sci 37:1811-1826

Morse TJ, Ebener MP, Koon EM, Morkert SB, Johnson DA, Cuddy DW, Weisser JW, Mullett KM, Genovese JH (2003) A case history of sea lamprey control in Lake Huron: 1979 to 1999. J Great Lakes Res 29(Suppl 1):599-614

Moser ML, Almeida PR, Kemp PS, Sorensen PW (2015) Lamprey spawning migration. In: Docker MF (ed) Lampreys: biology, conservation and control. Springer, Berlin, pp 215-263

Mota, MFR (2014) Biology and ecology of the allis shad, Alosa alosa (Linnaeus, 1758), in the Minho river. PhD dissertation. Instituto de Ciências Biomédicas Abel Salazar da Universidade do Porto

Mullett KM, Heinrich JW, Adams JV, Young RJ, Henson MP, McDonald RB, Fodale MF (2003) Estimating lake-wide abundance of spawning phase sea lampreys (Petromyzon marinus) in the Great Lakes: extrapolating from sampled streams using regression models. J Great Lakes Res 29(Suppl 1):240-252

Murdoch SP, Docker MF, Beamish FWH (1992) Effect of density and individual variation on growth of sea lamprey (Petromyzon marinus) larvae in the laboratory. Can J Zool 70:184-188

Neave FB (2004) The utility of meristic, morphometric, pigmentation and gonad analysis on the identification of Ichthyomyzon lamprey larvae. MS thesis, University of Guelph

Neeson TM, Koonce JF, Whiting PJ (2008) Factors affecting accuracy of stream channel slope estimates derived from geographical information systems. N Am J Fish Manage 28:722-732

O'Connor LM (2001) The proportion of introduced sea lampreys (Petromyzon marinus) that spawn in two streams tributary to Lake Ontario. MS Thesis, University of Guelph

Ojutkangas E, Aronen K, Laukkanen E (1995) Distribution and abundance of river lamprey (Lampetra fluviatilis) ammocoetes in the regulated river Perhonjoki. Regul River 10:239-245

Oliveira JM, Ferreira MT, Pinheiro AN, Bochechas JH (2004) A simple method for assessing minimum flows in regulated rivers: the case of sea lamprey reproduction. Aquat Cons 14:481-489

Patrick HK, Sutton TM, Swink WD (2009) Lethality of sea lamprey parasitism on lake sturgeon. Trans Am Fish Soc 138:1065-1075

Piavis GW (1961) Embryological stages in the sea lamprey and effects of temperature on development. Fish Bull 61:111-143

Potter IC (1980) Ecology of larval and metamorphosing lampreys. Can J Fish Aquat Sci 37:1641-1657
Potter IC, Beamish FWW (1977) The freshwater biology of adult anadromous sea lampreys Petromyzon marinus. J Zool Lond 181:113-130

Potter IC, Huggins RJ (1973) Observations on the morphology, behaviour and salinity tolerance of downstream migrating River lampreys (Lampetra fluviatilis). J Zool Lond 169:365-379

Potts DD, Dawson HA, Jones ML (2015) Validation of a relationship between statolith size and age of larval Great Lakes sea lamprey (Petromyzon marinus). Environ Biol Fish 98:1859-1869

Purvis HA (1979) Variation in growth, age at transformation, and sex ratio of sea lampreys re-established in chemically treated tributaries of the Upper Great Lakes. Great Lakes Fishery Commission, Technical Report 35, Ann Arbor, Michigan

Purvis HA (1980) Effects of temperature on metamorphosis and the age and length at metamorphosis in sea lamprey (Petromyzon marinus) in the Great Lakes. Can J Fish Aquat Sci 37:1827-1834

Quintella BR (2006) Biology and conservation of the sea lamprey (Petromyzon marinus L.) in Portugal. PhD thesis, University of Lisbon

Quintella BR, Andrade NO, Almeida PR (2003) Distribution, larval stage duration and growth of the sea lamprey ammocoetes, Petromyzon marinus L., in a highly modified river basin. Ecol Freshw Fish 12:1-8

Quintella BR, Andrade NO, Koed A, Almeida PR (2004) Behavioural patterns of sea lampreys spawning migration during difficult passage areas studied by electromyogram telemetry. J Fish Biol 65:1-12

Quintella BR, Andrade NO, Espanhol R, Almeida PR (2005) The use of PIT telemetry to study movements of ammocoetes and metamorphosing sea lampreys in river beds. J Fish Biol 66:97-106

Quintella BR, Andrade NO, Dias NM, Almeida PR (2007) Laboratory assessment of sea lamprey larvae burrowing performance. Ecol Freshw Fish 16:177-182

Quintella BR, Povoa I, Almeida PR (2009) Swimming behaviour of upriver migrating sea lamprey assessed by electromyogram telemetry. J Appl Ichthyol 25:46-54

Rahel FJ, Olden JD (2008) Assessing the effects of climate change on aquatic invasive species. Conserv Biol 22:521-533

Renaud CB (1997) Conservation status of Northern Hemisphere lampreys (Petromyzontidae). J Appl Ichthyol 13:143-148

Rodriguez-Muñoz R, Nicieza AG, Brana F (2003) Density-dependent growth of sea lamprey larvae: evidence for chemical interference. Funct Ecol 17:403-408

Rodríguez-Muñoz R, Nicieza AG, Braña F (2001) Effects of temperature on developmental performance, survival, and growth of sea lamprey embryos. J Fish Biol 58:475-486

Rodríguez-Muñoz R, Waldman JR, Grunwald C, Roy NK, Wirgin I (2004) Absence of shared mitochondrial DNA haplotypes between sea lamprey from North American and Spanish rivers. J Fish Biol 64:783-787

Rooney SM, Wightman G, Ó'Conchúir R, King JJ (2015) Behaviour of sea lamprey (Petromyzon marinus L.) at manmade obstacles during upriver spawning migration: use of telemetry to assess efficacy of weir modifications for improved passage. Biol Environ Proc R Irish Acad 115B:125-136 
Scribner KT, Jones ML (2002) Genetic assignment of larval parentage as a means of assessing mechanisms underlying adult reproductive success and larval dispersal. Great Lakes Fishery Commission, Research Completion Report, Ann Arbor, Michigan

Sepúlveda MS, Patrick HK, Sutton TM (2012) A single sea lamprey attack causes acute anemia and mortality in lake sturgeon. J Aquat Anim Health 24:91-99

Siefkes MJ, Steeves TB, Sullivan WP, Twohey MB, Li W (2013) Sea lamprey control: past, present, and future. In: Taylor WW (ed) Great Lakes fisheries policy \& management: a binational perspective. Michigan State University Press, East Lansing, pp 651-704

Silva S, Servia MJ, Vieira-Lanero R, Barca S, Cobo F (2013a) Life cycle of the sea lamprey Petromyzon marinus: duration of and growth in the marine life stage. Aquat Biol 18:59-62

Silva S, Servia MJ, Vieira-Lanero R, Cobo F (2013b) Downstream migration and hematophagous feeding of newly metamorphosed sea lampreys (Petromyzon marinus Linnaeus, 1758). Hydrobiologia 700:277-286

Sitar SP, Bence JR, Johnson JE, Ebener MP, Taylor WW (1999) Lake trout mortality and abundance in southern Lake Huron. N Am J Fish Manage 19:881-900

Slade JW, Adams JV, Christie GC, Cuddy DW, Fodale MF, Heinrich JW, Quinlan HR, Weise JG, Weisser JW, Young RJ (2003) Techniques and methods for estimating abundance of larval and metamorphosed sea lampreys in Great Lakes tributaries, 1995 to 2001. J Great Lakes Res 29(Suppl 1):137-151

Smith BR (1971) Sea lampreys in the Great Lakes of North America. In: Hardisty MW, Potter IC (eds) The biology of lampreys, vol 1. Academic Press, New York, pp 207-247

Smith PW (1979) The fishes of Illinois. University of Illinois Press, Urbana

Smith CL (1985) The inland fishes of New York State. New York State Department of Environmental Conservation, Albany

Smith SE (2013) Sublethal immune, endocrine and bioenergetics response to sea lamprey parasitism in two lake trout morphotypes from Lake Superior. MS thesis, Michigan State University, East Lansing

Smith BR, Tibbles JJ (1980) Sea lamprey (Petromyzon marinus) in Lakes Huron, Michigan, and Superior: history of invasion and control, 1936-78. Can J Fish Aquat Sci 37:1780-1801

Smith JJ, Kuraku S, Holt C, Sauka-Spengler T, Jiang N, Campbell MS, Yandell MD, Manousaki T, Meyer A, Bloom OE, Morgan JR, Buxbaum JD, Sachidanandam R, Sims C, Garruss AS, Cook M, Krumlauf R, Wiedemann LM, Sower SA, Decatur WA, Hall JA, Amemiya CT, Saha NR, Buckley KM, Rast JP, Das S, Hirano M, McCurley N, Guo P, Rohner N, Tabin CJ, Piccinelli P, Elgar G, Ruffier M, Aken BL, Searle SMJ, Muffato M, Pignatelli M, Herrero J, Jones M, Brown CT, Chung-Davidson Y-W, Nanlohy KG, Libants SV, Yeh C-Y, McCauley DW, Langeland JA, Pancer Z, Fritzsch B, de Jong PJ, Zhu B, Fulton LL, Theising B, Flicek P, Bronner ME, Warren WC, Clifton SW, Wilson RK, Li W (2013) Sequencing of the sea lamprey (Petromyzon marinus) genome provides insights into vertebrate evolution. Nat Genet 45:415-421
Sorensen PW, Vrieze LA (2003) Chemical ecology and potential application of the sea lamprey migratory pheromone. J Great Lakes Res 29(Suppl 1):66-84

Spangler GR, Robson DS, Regier HA (1980) Estimates of lamprey-induced mortality in whitefish, Coregonus clupeaformis. Can J Fish Aquat Sci 37:2146-2150

Stapanian MA, Madenjian CP, Bronte CR, Ebener MP, Lantry BF, Stockwell JD (2008) Status of burbot populations in the Laurentian Great Lakes. Am Fish Soc Symp 59:111-130

Steeves TB (2002) Uncertainty in estimating sea lamprey (Petromyzon marinus) abundance in Great Lakes tributaries. MS Thesis, Michigan State University, East Lansing

Stier K, Kynard BB (1986) Abundance, size and sex ratio of adult sea-run sea lampreys, Petromyzon marinus, in the Connecticut river. Fish Bull 84:476-480

Sugiyama H, Goto A (2002) Habitat selection by larvae of a fluvial lamprey, Lethenteron reissneri in a small stream and in an experimental aquarium. Ichthyol Res 49:62-68

Sullivan WP (2003) Substrate as a correlate of density and distribution of larval sea lampreys in streams. MS Thesis, University of Guelph

Sullivan WP, Adair R (2010) Integrated Management of Sea Lampreys in the Great Lakes 2009. Great Lakes Fishery Commission, Annual Report, Ann Arbor, Michigan

Sullivan WP, Adair R (2014) Integrated management of sea lampreys in the Great Lakes 2013. Great Lakes Fishery Commission, Annual Report, Ann Arbor, Michigan

Sullivan WP, Morrison BJ, Beamish FWH (2008) Adaptive cluster sampling: estimating density of spatially autocorrelated larvae of the sea lamprey with improved precision. J Great Lakes Res 34:86-97

Sutton TM, Bowen SH (1994) Significance of organic detritus in the diet of larval lampreys in the Great Lakes basin. Can J Fish Aquat Sci 51:2380-2387

Swink WD (1995) Growth and survival of newly parasitic sea lampreys at representative winter temperatures. Trans Am Fish Soc 124:380-386

Swink WD (2003) Host selection and lethality of attacks by sea lamprey (Petromyzon marinus) in laboratory studies. J Great Lakes Res 29(Suppl 1):307-319

Swink WD, Johnson NS (2014) Growth and survival of sea lampreys from metamorphosis to spawning in Lake Huron. Trans Am Fish Soc 143:380-386

Taverny C, Elie P (2009) Bilan des connaissances biologiques et de l'etat des habitats des lamproies migratrices dans le bassin de la Gironde-Propositions d'actions prioritaires. Rapport Final. Etude Cemagref, no. 123 Groupement de Bordeaux, Bourdeaux. France

Taverny C, Lassalle G, Ortusi I, Roqueplo C, Lepage M, Lambert P (2012) From shallow to deep waters: habitats used by larval lampreys (genus Petromyzon and Lampetra) over a western European basin. Ecol Freshw Fish 21:87-99

Thomas JD (1962) Observations on ecology of ammocetes Petromyzon marinus L. and Entosphenus lamottei. MS Thesis, University of Toronto

Thresher RE (2008) Autocidal technology for the control of invasive fish. Fisheries 33:114-121

Thresher RE, Hayes K, Bax NJ, Teem J, Benfey TJ, Gould F (2014) Genetic control of invasive fish: technological 
options and its role in integrated pest management. Biol Invasions 16:1201-1216

Torgerson CE, Close DA (2004) Influence of habitat heterogeneity on the distribution of larval Pacific lamprey (Lampetra tridentata) at two spatial scales. Fresh Biol 49:614-630

Trautman MB (1981) The fishes of Ohio. The Ohio State University Press, Columbus

Treble AJ, Jones ML, Steeves TB (2008) Development and evaluation of a new predictive model for metamorphosis of Great Lakes larval sea lamprey (Petromyzon marinus) populations. J Great Lakes Res 34:404-417

van Ginneken VJT, Maes GE (2005) The European eel (Anguilla anguilla, Linnaeus), its lifecycle, evolution and reproduction: a literature review. Rev Fish Biol Fish 15:367-398

Volk EC (1986) Use of calcareous otic elements (statoliths) to determine age of sea lamprey ammocoetes (Petromyzon marinus). Can J Fish Aquat Sci 43:718-722

Vrieze LA, Bjerselius R, Sorensen PW (2010) Importance of the olfactory sense to migratory sea lampreys Petromyzon marinus seeking riverine spawning habitat. J Fish Biol 76:949-964

Vrieze LA, Bergstedt RA, Sorensen PW (2011) Olfactory-mediated stream finding behavior of migratory adult sea lamprey (Petromyzon marinus). Can J Fish Aquat Sci 68:523-533

Waldman J, Grunwald C, Wirgin I (2008) Sea lamprey Petromyzon marinus: an exception to the rule of homing in anadromous fishes. Biol Lett 4:659-662

Waldman J, Daniels R, Hickerson M, Wirgin I (2009) Mitochondrial DNA analysis indicates sea lampreys are indigenous to Lake Ontario: response to comment. Trans Am Fish Soc 138:1190-1197

Webb PW (1978) Hydrodynamics: nonscombroid fish. In: Hoar WS, Randall DJ (eds) Fish physiology, vol 7. Academic Press, New York, pp 189-237

Weise JG, Pajos TA (1998) Intraspecific competition between larval sea lamprey year-classes as Salem Creek was recolonized, 1990-1994, after a lampricide application. N Am J Fish Manage 18:561-568

Wells L, McLain AL (1973) Lake Michigan—man's effects on native fish stocks and other biota. Great Lakes Fishery Commission, Technical Report 20, Ann Arbor, Michigan

Wicks BJ, Barker LA, Morrison BJ, Beamish FWH (1998) Gonadal variation in Great Lakes sea lamprey, Petromyzon marinus, larvae. J Great Lakes Res 24:962-968
Yap MR, Bowen SH (2003) Feeding by northern brook lamprey (Ichthyomyzon fossor) on sestonic biofilm fragments: habitat selection results in ingestion of a higher quality diet. J Great Lakes Res 29(Suppl. 1):15-25

Young RJ, Kelso JRM, Weise JG (1990a) Occurrence, relative abundance, and size of landlocked sea lamprey (Petromyzon marinus) ammocoetes in relation to stream characteristics in the Great Lakes. Can J Fish Aquat Sci 47:1773-1778

Young RJ, Houston KA, Weise JG, Kelso JRM (1990b) The effect of environmental variables on the population dynamics of sea lamprey, Petromyzon marinus. Can Tech Rep Fish Aquat Sci 1736, Sault Ste Marie, Ontario

Young RJ, Jones ML, Bence JR, McDonald RB, Mullett KM, Bergstedt RA, McDonald RB (2003) Estimating parasitic sea lamprey abundance in Lake Huron from heterogeneous data sources. J Great Lakes Res 29(Suppl. 1):214-225

Youson JH (1980) Morphology and physiology of lamprey metamorphosis. Can J Fish Aquat Sci 37:1687-1710

Youson JH (1994) Environmental and hormonal cues and endocrine glands during lamprey metamorphosis. In: Davey KG, Peter RE, Tobe SS (eds) Perspectives in comparative endocrinology. National Research Council of Canada, Ottawa, pp 400-408

Youson JH (1999) The lability and endocrinology of lamprey metamorphosis: an ancient developmental strategy. In: Roubos EW, Wendelaar Bonga SE, Vaudry H, De Loof A (eds) Recent developments in comparative endocrinology and neurobiology. Shaker, Maastrict, pp. 285-288

Youson JH (2003) The biology of metamorphosis in sea lampreys: endocrine, environmental and physiological cues and events and their potential application to lamprey control. J Great Lakes Res 29(Suppl. 1):26-49

Youson JH, Wright GM, Oot EC (1977) The timing of changes in several internal organs during metamorphosis of anadromous larval lamprey, Petromyzon marinus L. Can J Zool 55:469-473

Youson JH, Plisetskaya EM, Leatherland JF (1994) Concentrations of insulin and thyroid hormones in the serum of landlocked sea lampreys (Petromyzon marinus) of three larval year classes, larvae exposed to two temperature regimes, and both during and after metamorphosis. Gen Comp Endocrinol 94:294-304

Zerrenner A (2004) Effect of density and age on larval sea lamprey growth and survival in three Lake Champlain streams. J Freshw Ecol 19:515-519 